\title{
Standing to Sue and Multiple Defendant Class Actions IN AUSTRAlia, Canada, and The UNITEd STATES
}

\author{
VINCE MORABITO*
}

Recent decisions by appellate courts in Australia, Canada, and the United States provide an ideal opportunity to explore an important issue concerning the class action procedure, which has been largely ignored by legal commentators in Australia and Canada and has received, in the author's opinion, inadequate attention in the United States. The issue in question concerns the availability of the class action device where the representative plaintiff is seeking to initiate a class proceeding against more than one defendant but does not have individual standing to sue all of the proposed defendants.
Les récentes décisions des cours d'appel de l'Australie, du Canada et des États-Unis fournissent l'occasion par excellence d'examiner la grande question relative à la procédure de recours collectif qui a été en grande partie ignorée par les commentateurs juridiques en Australie et au Canada et qui a reçu, selon l'auteur, une attention inadéquate aux États-Unis. La question concerne la disponibilité $d u$ recours collectif lorsque le demandeur représentatif désire intenter un recours collectif contre plus d'un défendeur mais n'a pas le droit individuel de poursuivre tous les défendeurs proposés.

\section{TABLE OF CONTENTS}

I. INTRODUCTION . . . . . . . . . . . . . . . . . . . . . . . . . 296

II. MULTIPLE DEFENDANT Class ACTIONS IN THE

Federal Court of Australia . . . . . . . . . . . . . . . . . . . . 299

A. PART IVA OF THE FEDERAL COURT OF AUSTRALIA ACT $1976 \ldots . .299$

B. THE EARLY VIEW ...................... 300

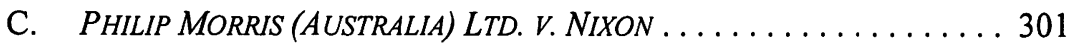

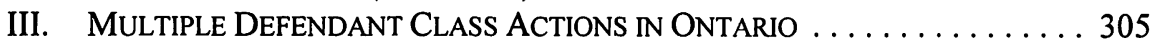

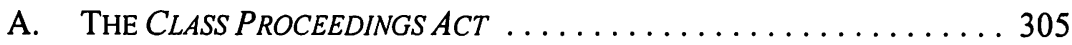

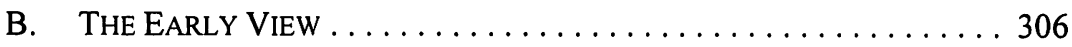

C. THE CuRrent View ....................... 306

D. CRITIQUE OF RAGOONANAN ESTATE $V$.

IMPERIAL TOBACCO CANADA LTD. . . . . . . . . . . . . . . . 308

IV. MULTIPLE DEFENDANT CLASS ACTIONS

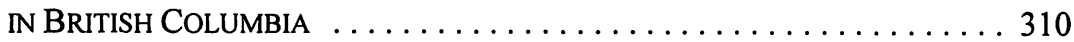

A. THE CLASS PROCEEDINGS ACT ................ 310

B. Minimal Restrictions ON Multiple

Defendant Class Actions . .................... 311

C. ANALYSIS OF CAMPBELL V. FLEXWATT CORP.,

HARRINGTON V. DOW CORNING,

AND FURLAN $V$. SHELL OIL .................. 313

V. Multiple Defendant Class Actions In the United States $\ldots \ldots . .319$

A. RULE 23 OF THE UNITED STATES FEDERAL RULES

OF CIVIL PROCEDURE .......................... 319

B. ARTICLE III OF THE U.S. CONSTITUTION $\ldots \ldots \ldots \ldots \ldots \ldots \ldots . \ldots \ldots$

B.Ec., LL.B. (Hons.), LL.M., Ph.D. (Mon.), Associate Professor, Department of Business Law and Taxation, Monash University (Victoria, Australia). The author wishes to thank Professor Garry Watson of Osgoode Hall Law School for his comments and suggestions on an earlier draft of this article. 
C. LA MAR V. H\& BNOVELTY \& LOAN ................ 323

D. THE CONSPIRACY/CONCERTED ACTION EXCEPTION $\ldots \ldots \ldots \ldots 328$

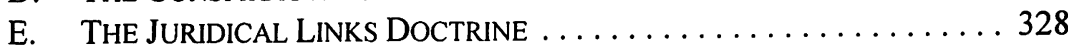

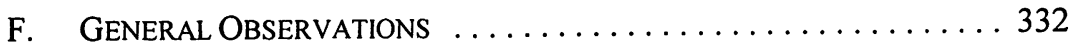

VI. CONCLUSION .................................... 332

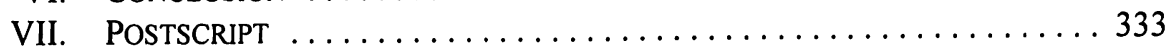

\section{INTRODUCTION}

Section 33C(1)(a) [of the Federal Court of Australia Act 1976(Cth)] requires every applicant and represented party to have a claim against the one respondent or, if there is more than one, against all respondents.'

In Ontario a statement of claim must disclose a cause of action against each defendant. Thus in a proposed class action, there must a representative plaintiff with a claim against each defendant. ${ }^{2}$

There is no requirement [in British Columbia] that there be a representative plaintiff with a cause of action against every defendant; the legislation simply requires that there be a cause of action. ${ }^{3}$

The plaintiff may represent [under Rule 23 of the United States Federal Rules of Civil Procedure] all those suffering an injury similar to his own inflicted by the defendant responsible for the plaintiff's injury, but in our view he cannot represent those having causes of action against other defendants against whom the plaintiff has no cause of action and from whose hands he suffered no injury. ${ }^{4}$

The comments above aptly illustrate the different responses that have been provided by the Federal Court of Australia and courts in Ontario, British Columbia, and the United States to an important issue concerning class actions initiated against more than one person (multiple defendant class actions). ${ }^{5}$ The issue is whether a multiple defendant class action

Philip Morris (Australia) Ltd. v. Nixon (2000), 170 A.L.R. 487 at 514 (F.C.A.), Sackville, Spender, and Hill JJ. [Philip Morris]. In the Federal Court of Australia plaintiffs are called applicants while defendants are referred to as respondents. For the sake of consistency, the terms plaintiff and defendant will be used throughout the article even when referring to Australian litigants. Hughesv. Sunbeam Corp. (Canada) Ltd. (2002), 61 O.R. (3d) 433 (C.A.) at para. 18, Laskin, Catzman, and Doherty, JJ.A.[Hughes].

Campbell v. Flexwatt Corp. (1997), 44 B.C.L.R. (3d) 343 at para. 42, Cumming, Newbury, and Huddart JJ.A., leave to appeal to S.C.C. refused [1998] S.C.C.A. No. 13 [Campbell].

La Mar v. H \& B Novelty \& Loan Co., 489 F.2d 461 at 462 (9th Cir. 1973) [La Mar].

The major differences between an ordinary action and a class action have recently been described by the Alberta Law Reform Institute, Class Actions, Final Report No. 85 (Edmonton: Alberta Law Reform Institute, 2000) at xix-xx [ALRI]:

In an ordinary action, each litigant is a party in their own right. In ... a class action ..., one party commences an action on behalf of other persons who have a claim to a remedy for the same or similar perceived wrong. That party conducts the action as 'representative plaintiff'. Only the 'representative plaintiff' is a formal party to the proceeding. Other persons having claims that share questions of law and fact with those of the representative plaintiff are members of the 'class.' Once the class has been determined, the class members are bound by the outcome of the litigation even though they generally do not participate in the proceedings.... A number of statutory safeguards and an expanded role for the court help to ensure that the interests of the class members are protected.

Instead of multiple separate proceedings deciding the same issues against the same defendant or defendants in proceedings brought by different plaintiffs, class actions decide common issues in one courtroom at one time.... These are the essential differences between an ordinary action and 
may be brought where the representative plaintiffs do not have a cause of action against all of the defendants, but each defendant has some class members who have a cause of action against that defendant. ${ }^{6}$

These divergent judicial approaches are partly attributable to differences in the various regimes governing the class action device in those four jurisdictions. They are also due to different judicial responses to the general and fundamental question of how the principles governing standing to $\mathrm{sue}^{7}$ are to apply in the context of group litigation, such as class actions. ${ }^{8}$ Broadly speaking, two general approaches exist to deal with standing in relation to class actions: the "class standing" theory and the "open door" theory. The first deals with standing

by reference to the general injury suffered in common by the class, rather than the personal injury suffered by the named plaintiff. On this view, ... the named plaintiff [is invested] with the injuries and grievances of

\section{a class action.}

6 The principles and rules that have been developed in relation to multiple defendant class actions are also applied to what are sometimes called bilateral class actions, that is, litigation where the named defendant is also a representative party, acting on behalf of a class/group of defendants. A different scenario exists in Ontario (see infra note 68). As was indicated by an American Court, the situation "in which a plaintiff having a cause of action against a single defendant sought to institute a class action against that defendant and additional defendants against whom the named plaintiff had no personal claim ... can arise either when a plaintiff seeks to have a defendant's class certified or in a simple case of joining several defendants" (Thompson v. Board of Education, 71 F.R.D. 398 at 407 (W.D. Mich. 1976) [Thompson]). See also Doss v. Long, 93 F.R.D. 112 at 119 (N.D. Ga. 1981) [Doss], "the last issue raised regarding the motion for class certification involves a problem unique to bilateral plaintiff class-defendant class litigation. It is the Rubik Cube puzzle: each plaintiff does not have a cause of action against each defendant": and Thillens Inc. v. Community Currency Exchange Association of Illinois, 97 F.R.D. 668 at 675 (N.D. III. 1983) [Thillens]: "there is a great judicial reluctance to certify a defendant class when the action is brought by a plaintiff class. The primary concern with bilateral actions ... is a fear that each plaintiff member has not been injured by each defendant member."

The class action regimes that are currently in place in the United States at the federal level, and in the Canadian province of Ontario, permit the prosecution of defendant class actions. The regimes that govern class actions in the Federal Court of Australia and in the Canadian province of British Columbia do not permit defendant class actions.

7 According to the Law Reform Commission of British Columbia, Civil Litigation in the Public Interest, Report No. 46 (Vancouver: Law Reform Commission of British Columbia, 1980) at 31 [LRCBC],

an individual's 'standing' denotes a legal capacity to institute proceeding and is used interchangeably with terms such as 'locus standi' and 'title to sue.' The purpose of the law of standing is to govern and guide who can raise questions for adjudication by the courts; it is not designed to control what questions may be decided by the courts, or how far the courts should substitute their judgment for that of legislators or administrators. The question of standing however, precedes the determination of a case on its merits, and in the result of a finding of no locus standi can prevent any judicial investigation into the substantive issue presented for determination.

8 See Haas v. Pittsburgh National Bank, 60 F.R.D. 604 at 611 (W.D. Pa. 1973) [Haas]: "[a] question which lies at the very heart of class actions ... [is] whether a plaintiff in a ... class action can maintain a suit against a named defendant if he cannot bring that action in his own right. The issue is one which requires the balancing of two important ... considerations: standing to sue and representative status." See also Mauro Cappelletti, "Governmental and Private Advocates for the Public Interest in Civil Litigation: A Comparative Study" (1975) 73 Mich. L. Rev. 793 at 855: "the struggle between the maintenance of these traditional rules [governing standing to sue] and the growth of class and publicinterest actions reflects perhaps the most heated ideological struggle of our century - between solitary individualism and laissez-faire, on the one hand, and a social conception of the law, the economy and the state's role, on the other." 
absent class members. He becomes their representative for standing purposes, as well as for purposes of conducting the litigation. If the class claim complies with [the prerequisites for a class action] and presents a justiciable issue, the named plaintiff's failure to show a personal injury will not preclude him from seeking redress for the class injury. ${ }^{9}$

The open door theory sees a class proceeding "as an aggregation of similar, independently justiciable claims. Plaintiff's right to represent a class is predicated upon his personal satisfaction of the standing requirement." ${ }^{10}$ The philosophy underpinning the theory appears to be that the rules governing individual or traditional litigation should be applied, as far as possible, to class proceedings. In light of the fact that the named plaintiff in individual proceedings must have standing, a similar requirement must be imposed upon the class representative since in class proceedings it is the class representative who is the named plaintiff — that is, the party on the record. " As indicated by Burger C.J. of the United States Supreme Court in Allee v. Medrano:

a named plaintiff cannot acquire standing to sue by bringing his action on behalf of others who suffered injury which would have afforded them standing had they been named plaintiffs; it bears repeating that a person cannot predicate standing on injury which he does not share. Standing cannot be acquired through the back door of a class action. ${ }^{12}$

On the one hand, the class standing theory recognizes, and seeks to cater to, the unique features of class proceedings. Its proponents point out that "[i]t recognizes both the special nature of the class action and the strength of arguments against granting uninjured plaintiffs access to the federal courts. ${ }^{\prime \prime 3}$ Application of the class standing theory to multiple defendant class actions appears to produce a clear scenario in which there is no need for every representative plaintiff and every class member to have a personal cause of action against every defendant. A multiple defendant class action may be prosecuted as long as it can be shown that for each defendant there are some members of the class/group who have personal causes of action against that defendant. On the other hand, employment of the open door theory in multiple defendant class actions does not necessarily provide clear requirements.

" S.M. Shafner, "The Juridical Links Exception to the Typicality Requirement in Multiple Defendant Class Actions: The Relationship between Standing and Typicality" (1978) 58 Boston U.L. Rev. 492 at 496.

10 Ibid. See also "Developments in the Law - Class Actions", Note (1976) 89 Harvard L. Rev. 1318 at 1466-72.

1 See Deposit Guaranty Guaranty National Bank v. Roper, 445 U.S. 326 at 344, n. 4 (1980); and Phillips Petroleum Co. v. Shutts, 472 U.S. 797 at 810 (1995). See also Scott v. TD Waterhouse Investor Services (Canada) Inc., (2001) 94 B.C.L.R. (3d) 320 at para. 114, Martinson J.; Dabbs v. Sunlife Assurance Co. of Canada (1998), 41 O.R. (3d) 97 at 99, Laskin, Charron, and O'Connor JJ.A.: "a representative plaintiff ... is a party to the proceeding and has the specific rights and responsibilities for the carriage of the litigation on behalf of the class that are set out in the [Ontario Act]"; and Mayo v. Hartford Life Insurance Co., 214 F.R.D. 465 (S.D. Tex. 2002) at 469: "the [representative plaintiffs], having made class action allegations, have the statutory duty to represent both their own individual, personal interests, as well as the interests of all potential class members." 416 U.S. 802 at $828-29$ (1974).

13 "Class Standing and the Class Representative", Note (1981) 94 Harvard L. Rev. 1637 at 1649 ["Class Standing"]. See also J.B. Conn, "Nominal Plaintiff Without Individual Standing May Represent Certified Class Where Adequate Representation is Shown" (1976) 45 Cincinnati L. Rev. 317 at 324; and M.K. Kane, "Standing, Mootness and Federal Rule 23 - Balancing Perspectives" (1977) 26 Buffalo L. Rev. 83 at 97. 
Whilst there is no doubt that the theory requires that for each defendant there be a representative plaintiff with a personal claim against that defendant, it is not entirely clear whether, where there are multiple representative plaintiffs, it further requires that each representative plaintiff must have a cause of action against each defendant.

This article explores how courts in the four jurisdictions have dealt with these and other related issues.

\section{Multiple Defendant Class ACtions in THE FEDERAL COURT OF AUSTRALIA}

\section{A. Part IVA OF THe Federal CoURT OF AUSTRALIA ACt $1976^{14}$}

Unlike class action regimes in the United States and Canada, Part IVA does not employ a certification regime. However, s. $33 \mathrm{C}(1)$ sets out the conditions which need to be satisfied in order to initiate a class proceeding under Part IVA. It provides that where

(a) 7 or more persons have claims against the same person; and

(b) the claims of all those persons are in respect of, or arise out of, the same, similar or related circumstances; and

c) the claims of all those persons give rise to a substantial common issue of law or fact;

a proceeding may be commenced by one or more of those persons as representing some or all of them. ${ }^{15}$

Furthermore, a proceeding which complies with all three requirements of s. $33 \mathrm{C}(1)$ may be discontinued as a Part IVA suit by the Federal Court of Australia if one of the scenarios specified in ss. $33 \mathrm{~L},{ }^{16} 33 \mathrm{M},{ }^{17}$ or $33 \mathrm{~N}^{18}$ is found to exist.

Another important provision of Part IVA is s. 33D(1) which provides that

(Cth.), Part IVA [Part IVA]. Part 4A of the Supreme Court Act 1986 (Vic.), recently enacted by the Parliament of Victoria, is very similar to Part IVA. Consequently, the analysis contained in this part is equally relevant to the Victorian regime. Ibid.

16 Ibid. It provides that where, at any stage of the class action, it appears likely that there are fewer than seven class members, the Court is empowered to order (a) that the proceeding continue as a class action or (b) that the proceeding no longer continue as a class action under Part IVA.

Ibid. It empowers the Court to order the termination or stay of a class action where the cost to the defendant of identifying the class members and distributing to them the damages won by the representative plaintiff would be excessive.

Ibid. The power conferred by this section is dependent on judicial satisfaction "that it is in the interests of justice" that a proceeding no longer continue under Part IVA because

(a) the costs that would be incurred if the proceeding were to continue as a class proceeding are

likely to exceed the costs that would be incurred if each class member conducted a separate proceeding; (b) all the relief sought can be obtained by means of a proceeding other than a class proceeding under [Part IVA]; (c) the class proceeding will not provide an efficient and effective means of dealing with the claims of the class members; or (d) it is otherwise inappropriate that the claims be pursued by means of a class proceeding.

Section 33P provides that where the Court orders the discontinuance of a class suit under ss. $33 \mathrm{~L}, 33 \mathrm{M}$, or $33 \mathrm{~N}$, "(a) the proceeding may be continued as a proceeding by the representative party on his or her own behalf ...; (b) and on the application of a person who was a group member for the purposes of the proceeding, the Court may order that the person be joined as an applicant in the proceeding." 
a person referred to in paragraph $33 \mathrm{C}(1)(\mathrm{a})$ who has a sufficient interest to commence a proceeding on his or her own behalf against another person has a sufficient interest to commence a representative proceeding against that other person on behalf of other persons referred to in that paragraph. ${ }^{19}$

\section{B. THE EARLY VIEW}

The early judicial pronouncements on Part IVA actions brought against multiple defendants provide fascinating reading. On the one hand, comments made by single justices of the Federal Court made it clear that for a multiple defendant class action to be brought under Part IVA, the named plaintiff must have a personal claim against each defendant. ${ }^{20} \mathrm{At}$ the same time, Part IVA actions were permitted despite the fact that the representative plaintiffs did not have claims against all defendants. ${ }^{21}$ An excellent illustration of this anomalous state of affairs was provided by the group litigation in Ryan v. Great Lakes Council. $^{22}$

The Part IVA proceeding in Ryan was brought against 12 defendants on behalf of persons who had suffered injury as a result of eating oysters from the Wallis Lakes in New South Wales that were contaminated with the Hepatitis A virus. The 12 defendants were oyster farmers, oyster distributors, and the Great Lakes Council (the Council), which was said to have certain legal responsibilities in relation to the quality of the water at the lake. The named plaintiff had a personal claim against only two defendants: the Council and an oyster farmer. The judge presiding, Wilcox J., expressed the view that as a result of s. $33 \mathrm{C}(1)(\mathrm{a})$,

[i]t follows that, in order to utilise the Pt. IVA procedure against a given respondent, the applicant must have a personal claim against that respondent that is shared by at least six other persons. The legislation does not prevent several respondents being joined to a single Pt. IVA proceeding, so long as the commencement and standing requirements are met by the applicant in respect of each of them. ${ }^{23}$

Compliance with this interpretation of s. $33 \mathrm{C}(1)$ (a) would have required one of two orders in Ryan: either replacement of the named plaintiff with someone who had a personal claim against each of the 12 defendants or, what was probably a more realistic option, dismissal of the proceedings against the ten defendants in relation to whom Ryan had no personal claim. Instead, additional representative plaintiffs were appointed. As Wilcox J. explained:

on 18 September 1997 I ruled that Mr. Ryan was not competent to maintain a representative action against a person in relation to whom he had no personal claim.... However, I subsequently gave leave Mr. Ryan to amend the proceeding in such a manner as to join additional applicants; each being a person who made a

Ibid., s. 33D(1). As explained by the Court in Femcare Ltd. v. Bright (2000), 172 A.L.R. 713 at para. 97, Black C.J., Sackville, and Emmett JJ., "[t]he representative procedure adopted in the Court of Chancery accorded the representative party standing to make claims on behalf of members of the represented group. Section 33D merely continues and adapts the same long-standing principle." 11. 
personal claim against a particular grower or distributor and was therefore competent to represent other group members who had claims against that grower or distributor. ${ }^{24}$

This appointment of additional representatives clearly indicates that, contrary to his comments as to the requirements of s. $33 \mathrm{C}(1)$ quoted above, ${ }^{25}$ Wilcox J. envisaged that compliance with s. $33 \mathrm{C}(1)$ (a) may be attained as long as it is shown that for each defendant there is a representative plaintiff making a personal claim against that defendant. It was not until a class action was launched against Australian manufacturers and distributors of cigarettes on behalf of persons suffering the ill effects of smoking that the Full Federal Court was required to grapple with the issue canvassed in this article.

\section{PHILIP MORRIS (AUSTRALIA) LTD. V. NIXON}

In Philip Morris (Australia) Ltd. v. Nixon, Sackville J. of the Federal Court (with whose reasons Spender and Hill JJ. agreed) held that

s. 33 C(1)(a) requires every applicant and represented party to have a claim against the one respondent or, if there is more than one, against all respondents. This conclusion follows from the language of s. $33 \mathrm{C}(1)(\mathrm{a})$ itself and is consistent with the approach taken by the [Australian Law Reform Commission] in Grouped Proceedings. It is also consistent with the structure of the legislation. For example, s. 33D(1)(a) (which provides that a person who has a sufficient interest to commence a proceeding on his or her own behalf against another person has a sufficient interest to commence a representative proceeding against that person on behalf of other persons referred to in $\mathrm{s} .33 \mathrm{C}(1)(\mathrm{a}))$ is clearly drafted on the assumption that all applicants and represented persons will have claims against the same person.

It follows that s. $33 \mathrm{C}(1)(\mathrm{a})$ is not satisfied if some applicants and group members have claims against one respondent (or group of respondents) while other applicants and group members have claims against another respondent (or group of respondents)... Of course, if there are two sets of claims against two sets of respondents, it may well be that each can be the subject of representative proceedings. It may even be that directions can be made for them to be heard together: Ryan v. Great Lakes Council (1997) 149 ALR 45, at 48 , per Wilcox J. But they cannot both be the subject of the same representative proceedings. ${ }^{26}$

According to this view, multiple defendant class actions may only be permitted where every named plaintiff and every class member make a claim against every defendant. As such, it represents the most restrictive approach that may be adopted with respect to the issue of standing in multiple defendant class actions. As will be shown in the remainder of this article, courts in the United States, Ontario, and British Columbia have not embraced this approach.

For the purpose of standing, Philip Morris treats multiple defendant class actions in precisely the same way that single defendant class actions are treated. As indicated in 1977 by the Law Reform Committee of South Australia, 
[t]he class action is essentially a procedural device by which a class of persons, who each individually have a good cause of action and locus standi to pursue it but are unable to do so effectively because the amount of the individual claims is disproportionate to the cost of litigating them, may enforce their rights through a representative plaintiff and by utilising the class action machinery. ${ }^{27}$

Unfortunately, it cannot be said that the requirements for the commencement of a Part IVA proceeding were construed by the Full Federal Court in Philip Morris in light of the objectives of the class action device. The policy goals of the class action device were recently articulated by the Supreme Court of Canada:

Class actions provide three important advantages over a multiplicity of individual suits. First, by aggregating similar individual actions, class actions serve judicial economy by avoiding unnecessary duplication in factfinding and legal analysis [the judicial economy goal]. Second, by distributing fixed litigation costs amongst a large number of class members, class actions improve access to justice by making economical the prosecution of claims that any one class member would find too costly to prosecute on his or her own [the access to justice goal]. Third, class actions serve efficiency and justice by ensuring that actual and potential wrongdoers modify their behaviour to take full account of the harm they are causing, or might cause, to the public [the behaviour modification goal]. ${ }^{28}$

The Supreme Court of Canada also persuasively argued that achieving the desirable benefits associated with the class action device requires that a generous approach be taken to the construction and application of class action legislation:

[T] he legislative history of [Ontario's] Class Proceedings Act 1992 makes clear that the Act should be construed generously ... it is essential ... that courts not take an overly restrictive approach to the legislation, but rather interpret the Act in a way that gives full effect to the benefits foreseen by the drafters. ${ }^{29}$

27 Law Reform Committee of South Australia, Report Relating to Class Actions, Thirty-Sixth Report (South Australia: Law Reform Committee of South Australia, 1977) at 11. See also Ragoonanan Estate v. Imperial Tobacco Canada Ltd. (2000), 51 O.R. (3d) 603 at 615 [Ragoonanan]: "the essence of a class proceeding is that it is an action with a representative plaintiff on behalf of a group of persons (a class) who have a cause of action in respect of which there are common issues of fact or law."

Hollick v. Toronto (City), [2001] 3 S.C.R. 158 at para. 15, McLachlin C.J.C. [Hollick]. The objectives which the Part IVA device seeks to attain were explained as follows in the Second Reading Speech of the Federal Court of Australia (Amendment) Bill 1991 (Cth.), which introduced Part IVA:

The Bill gives the Federal Court an efficient and effective procedure to deal with multiple claims. Such a procedure is needed for two purposes. The first is to provide a real remedy where, although many people are affected and the total amount at issue is significant, each person's loss is small and not economically viable to recover in individual actions. It will thus give access to the courts to those in the community who have been effectively denied justice because of the high cost of taking action. The second purpose of the Bill is to deal efficiently with the situation where the damages sought by each claimant are large enough to justify individual actions and a large number of persons wish to sue the respondent. The new procedure will mean that groups of persons, whether they be shareholders or investors, or people pursuing consumer claims, will be able to obtain redress and do so more cheaply and efficiently than would be the case with individual actions.

See Austl. Commonwealth, House of Representatives, Parliamentary Debates (14 November 1991) at 3174 (Michael Duffy, Attorney-General).

Hollick, ibid. at paras. 14-15. See also Femcare Ltd. (2000), 172 A.L.R. 713 at 728, 730, Black C.J., Sackville, and Emmett JJ.; Wong v. Silkfield Pty Ltd. (1999), 165 A.L.R. 373 at 381, Gleeson C.J., McHugh, Gummow, Kirby. and Callinan JJ.; Johnson Tiles Pty. Ltd. v. Esso Australia Pty. Ltd., [1999] FCA 56 at para. 49, Merkel J.; and Johnson Tiles Pty. Ltd. v. Esso Australia Pty. Ltd. (No. 3), [2001] VSC 372 at paras. 32,33 , and 50, Gillard J. 
The Philip Morris ruling is not in accordance with the philosophy outlined above as it has adversely affected the ability of Part IVA to enhance access to justice in relation to legal disputes involving multiple claimants and multiple defendants. ${ }^{30}$ Evidence of this unsatisfactory state of affairs is furnished by the fact that the proceeding in Philip Morris itself, ${ }^{31}$ as well as a number of other multiple defendant class actions initiated under Part IVA, were terminated ${ }^{32}$ as class proceedings by the Federal Court. The termination was primarily a result of the inability of the representative plaintiffs to demonstrate that every representative plaintiff and every class member had a personal claim against every defendant. $^{33}$ The unsatisfactory nature of the Australian scenario in relation to multiple defendant class actions is also emphasized by the following factors:

- The terms of ss. $33 \mathrm{C}(1)$ and $33 \mathrm{D}(1)$ do not compel the conclusion arrived at in Philip Morris. $^{34}$

- The report of the Australian Law Reform Commission ${ }^{35}$ that provided the impetus for Part IVA, and was greatly relied upon in Philip Morris, does not support the restrictive construction embraced by the Full Federal Court. ${ }^{36}$

- Comments made by the Minister who introduced the Part IVA legislation in the Australian Senate indicate that the government responsible for the introduction of that

30 "The present case affords a good example of how the strict application of s. $33 \mathrm{C}(1)(\mathrm{a})$, in a case involving more than one respondent, might give rise to requirements and limitations that have little to do with the purpose or efficacy of Pt. IVA" (Bray v. F. Hoffman-La Roche Ltd., [2002] FCA 1405 at para. 9, Merkel J. [Bray]). See also P. Gordon \& L. Nichols, "The Class Struggle" (2001) 48 Plaintiff 6 at 10 :

on one reading of the approach by some Judges of the Federal Court to complex cases involving more than one respondent, particularly where the conduct in question involves a complicated or lengthy series of transactions, those cases should simply not be brought as class actions. If that reading is correct, then to put it bluntly, defendants are more likely to escape liability if by their conduct they cause harm or loss to more people over a greater period of time, and if they do so in concert with others.

31 According to Sackville J., s. 33C(1)(a) had not been satisfied because "the statement of claim pleads that some applicants and group members have claims against one respondent, while others have claims against the other individual respondents" (Philip Morris, supra note 1 at 521).

32 Problems associated with the Philip Morris approach were described by Kane, supra note 13 at 95-96:

to require the class representative to show that every class member's claim presents an actual controversy would place a formidable, if not insurmountable, threshold burden on the courts and parties. Moreover ... to require proof of the existence of individualized 'cases' would in essence be treating the class members as parties. To do that is inconsistent with the representative character of the proceedings.

33 See Bright v. Femcare Ltd., [2000] FCA 742 at para. 81; Batten v. CTMS Ltd., [2000] FCA 915; Hunter Valley Community Investments Pty. Ltd. v. Bell, [2001] FCA 201 [Hunter Valley] and [2001] FCA 1148; Sereika v. Cardinal Financial Services Ltd., [2001] FCA 1715; and Milfull v. Terranora Lakes Country Club Ltd., [2002] FCA 178. The application of Philip Morris by the Supreme Court of Victoria to the Victorian equivalent of Part IVA has also resulted in the termination of a multiple defendant class action in Cook v. Pasminco Ltd., [2000] VSC 534.

34 See e.g. J. Beach, "Representative Proceedings - Some Current Issues" (Paper presented at a Seminar on Recent Developments in Class Actions, Melbourne, October 2000) at 23 [unpublished]; and Bray, supra note 30 at para. 9: "while it is clear that s. $33 \mathrm{C}(1)(\mathrm{a})$ requires that the applicant and each group member have a claim against the respondent it is not altogether clear that the same requirement was intended to apply where there were multiple respondents."

35 Law Reform Commission, Grouped Proceedings in the Federal Court Report No. 46 (Canberra: Australian Government Publishing Service, 1988).

36. See Morabito, supra note 20 at 300-302 
legislation envisaged the use of the Part IVA regime in circumstances now precluded by Philip Morris. ${ }^{37}$

- Part IVA vests the Federal Court with sufficient powers to deal with any difficulties that are likely to arise in managing a class action that involves multiple defendants. ${ }^{38}$ Consequently, the principle enunciated in Philip Morris was not necessary in order to prevent proceedings which are unmanageable or which generate unfair scenarios for class members or defendants.

That being said, the Australian multiple defendant class actions landscape is not entirely unsatisfactory. Shortly after Philip Morris, a differently constituted Full Federal Court in King v. GIO Australia Holdings Ltd. ${ }^{39}$ embraced a generous interpretation of what the s. $33 \mathrm{C}(1)$ (a) concept of having claims against the same person entails. King concerned advice provided to the shareholders of GIO as to whether a takeover offer should have been accepted. The class was described as GIO shareholders, who did not accept the takeover offer "by reason of the conduct ... of all.(or alternatively, any) of the Respondents and who suffered loss as a consequence." ${ }^{40}$ Wilcox, Lehane, and Merkel JJ. rejected the argument advanced by the defendants that the use of the alternative "any" demonstrated that the proceeding failed to comply with $\mathrm{s} .33 \mathrm{C}(1)(\mathrm{a})$ in that it did not disclose a claim by each class member against each defendant:

The alternative "any" means that a person is a group member if he or she, as a matter of fact, suffered loss as a result of the conduct of any respondent. This is necessary to cover the situation of a group member who, although claiming against all respondents, only suffered loss by reason of the conduct of one of the respondents. That person is still to be regarded as a group member and, accordingly, is bound by the result.

The fact that a person is ultimately adjudged to be entitled to succeed against only one respondent, does not mean that a person makes a claim against only that respondent. There is a world of difference between a claim and success on the claim. ${ }^{41}$

The approach followed in King, if implemented in future cases, is likely to ameliorate the harsh impact that Philip Morris has had upon multiple defendant class actions ${ }^{42}$ It should also be added that the Full Federal Court has allowed Part IVA proceedings to be brought by entities which had no interests of their own to protect in the litigation and whose individual standing to sue was only statutory. ${ }^{43}$

Ibid. at 307-308.

As was indicated by the trial judge in Nixon v. Philip Morris (Australia) Ltd. (1999), 165 A.L.R. 515 at 546, Wilcox J., "[i]f at any stage a conflict of interest emerges, between particular classes of group members or particular individuals, that will not necessarily make it impossible or inappropriate to maintain the proceeding as a representative action. It might prove possible to meet any difficulty by the constitution of sub-groups, and the appointment of sub-group representatives." See also Part IVA, supra note 14 at s. $33 \mathrm{ZF}(1)$ which empowers the Federal Court to make "any order ... [it] thinks appropriate or necessary to ensure that justice is done in the proceedings."

[2000] FCA 1543, Wilcox, Lehane, and Merkel JJ [King].

Ibid. at para. 6.

Ibid. at paras. 6-7.

See, e.g. Bray, supra note 30 at paras. 45-48.

See Finance Sector Union of Australia v. Commonwealth Bank of Australia (1999), 166 A.L.R. 141 at 146-47, where Wilcox, Ryan, and Madgwick JJ. noted that, "if a statutory provision, like s. 80 of the Trade Practices Act, allows 'any person' to bring an action for contravention, this means that any 


\section{Multiple Defendant Class Actions in ONTARio}

\section{A. The Class PRoCEEDINGS ACT}

A class action may proceed in Ontario under s. 5 of the Class Proceedings $A c t^{44}$ only after the court certifies that the class and the named plaintiffs meet five requirements. The first requirement is that the pleadings "disclose [a] cause of action." 45 The second is that "there is an identifiable class of two or more persons that would be represented by the representative plaintiff or defendant." 46 The third is that "the claims or defences of the class members raise common issues." The fourth criteria is that "a class proceeding would be the preferable procedure for the resolution of the common issues." 47 The final requirement is that "there is a representative plaintiff or defendant who

(i) would fairly and adequately represent the interests of the class, (ii) has produced a plan for the proceeding that sets out a workable method of advancing the proceeding on behalf of the class and of notifying class members of the proceeding, and (iii) does not have, on the common issues for the class, an interest in conflict with the interests of other class members. ${ }^{48}$

An additional requirement that has been regarded by Ontario courts as of some importance in the context of multiple defendant class actions is one which, ironically, is not found in the Ontario Act, but is found in the rules of court. The requirement in question is that a pleading must disclose a "reasonable cause of action." 49

As shown below, the Ontario approach to the issue canvassed in this article mirrors the Australian experience in that the initially generous approach to the prerequisites for the commencement of multiple defendant class actions has been followed by a recent imposition of additional requirements. However, unlike the Australian regime, the change of judicial approach in Ontario has not resulted in the erection of formidable barriers to the commencement of multiple defendant class actions.

person has a sufficient interest to commence a proceeding on his or her own behalf. Section $33 \mathrm{D}(1)$ is satisfied. The person may act as a representative applicant on behalf of others." In the United States, on the other hand, the Supreme Court has indicated that "Congress may grant an express right of action to persons who otherwise would be barred by prudential standing rules [but] the plaintiff must still allege a distinct and palpable injury to himself, even if it is an injury shared by a large class of other possible litigants" (Warth v. Seldin, 422 U.S. 490 at 501 (1975)). S.O. 1992, c. 6 [Ontario Act].

Ibid., s. 5. The Supreme Court of Canada has indicated that "the class representative must show some basis in fact for each of the certification requirements set out in $\mathrm{s}$. 5 of the Act, other than the requirement that the pleadings disclose a cause of action. That latter requirement is of course governed by the rule that a pleading should not be struck for failure to disclose a cause of action unless it is 'plain and obvious' that no claim exists" (Hollick, supra note 28 at para. 25).

Ontario Act, ibid.

Ibid.

Ibid.

Rules of Civil Procedure, R.R.O. 1990, Reg. 194, r. 21.01(1)(b) [Rules]. 


\section{B. THE EARLY VIEW}

In Bendall v. McGhan Medical, ${ }^{50}$ a class action was commenced by two named plaintiffs, Bendall and Wise, against three manufacturers of breast implants: McGhan Medical Corp. (McGhan), Dow Corning Canada Inc., and Dow Corning Corp. (collectively, Dow Corning). Bendall had a cause of action against McGhan only while Wise had a personal claim against Dow Corning only. The class members were in a similar position, as each had a claim against either McGhan or Dow Corning, but not both.

This state of affairs prompted the defendants to put forward the proposition that certification should be denied by the Court. That proposition was rejected by Montgomery J.: "The first objection by McGhan is that Wise has no cause of action against McGhan. Similarly Bendall has no cause of action against Dow Corning. However, each plaintiff has a cause of action against one of the defendants; the pleadings therefore disclose a cause of action as required by s. $5(\mathrm{a}) . "{ }^{.51}$

Bendall exhibits a broad and liberal interpretation of the prerequisites for class proceedings which, unlike the Australian regime, does not require each representative plaintiff and each class member to have a cause of action against each defendant. The following comments made in 2000 by Farley and Cumming JJ. of the Ontario Superior Court of Justice, respectively, give the clear impression that the Ontario Act also permits the prosecution of multiple defendant class actions where the representative plaintiff has a cause of action against at least one of the defendants and there are class members with a cause of action against the other defendants:

There is no requirement that the representative plaintiffs have a cause of action against every defendant, provided that he or she can adequately advance the class interests against all defendants with respect to the common issues. $^{52}$

It is unnecessary in a class proceeding for the representative plaintiff to personally have a cause of action against each named defendant. It is sufficient for a representative plaintiff to represent a proposed class of persons who may be able to assert claims against the various defendants. ${ }^{53}$

A mere two months after making the comments noted above, Cumming J. in Ragoonanan ${ }^{54}$ adopted a somewhat less liberal approach to multiple defendant class actions.

\section{The CURRENT VieW}

The class proceedings in Ragoonanan were initiated as a result of a fire that occurred in the residence of the named plaintiffs. The cause of the fire was an unextinguished cigarette which was manufactured by the first defendant, Imperial Tobacco Canada Ltd. (ITCL). The

(1993), 14 O.R. (3d) 734 [Bendall].

Ibid. at 744 .

Millard v. North George Capital Management Ltd. (2000), 47 C.P.C. (4th) 365 (Ont. Sup. Ct.) at para. 43, Farley J.

Gariepy v. Shell Oil (2000), 51 O.R. (3d) 181 at 185, Cumming J.

Supra note 27. 
class proceedings were commenced, not just against ITCL, but also against the two other suppliers of cigarettes in Canada: Rothmans Inc., Benson \& Hedges Inc. (RBH) and JTIMacDonald Inc. (JTI-M). The class was described as "persons in Canada who suffered a loss or injury as a result of a fire after October 1, 1987 which occurred when a cigarette ignited upholstered furniture or a mattress; the estates of persons who died in any such fires; and persons with a derivative claim." "5s The substantive basis of those proceedings was that the injuries, deaths and property losses suffered by the representative plaintiffs and class members could have been avoided if the cigarettes sold by the defendants had been fire safe cigarettes. ${ }^{56}$ The representative plaintiffs did not allege to have personal causes of action against RBH and JTI-M. Instead, they submitted that each defendant had some putative class members with a cause of action against that defendant.

At the pre-certification stage of the class proceedings, the defendants moved under $r$. 21.01(1)(b) to strike the named plaintiff's pleading on the ground that "it discloses no reasonable cause of action." The essence of the submission put forward by the defendants was that it is not enough that some members of the class would have a cause of action on the face of the pleading against RBH and JTI-M. What is also required is that for any given defendant there is at least one named plaintiff who has "a reasonable cause of action" disclosed in the pleading against that defendant. Consequently, the defendants submitted that the class proceedings could only proceed against ITCL and not continue against RBH and JTI-M.

Cumming J. reviewed a number of British Columbia judgments, discussed below, in which multiple defendant class actions were certified in circumstances where the class representatives did not have causes of action against every defendant. However, he distinguished those decisions on the basis that they dealt with motions for certification and not with pre-certification motions brought under British Columbia's counterpart ${ }^{57}$ to Ontario's r. 21.01(1)(b). The court in Ragoonanan also indicated that in the context of a certification motion, "there is arguably not a prerequisite required by s. $5(1)(a)^{58}$ to have a representative plaintiff with a cause of action against each defendant ... it may be enough if the pleading provides that class members have a cause of action against the defendants and there is at least one representative plaintiff." 59

However, a stricter approach was followed by the Court with respect to the requirements of r. 21.01(1)(b), as it was held that this rule requires that for every defendant there is a named plaintiff with a cause of action against that defendant. Rule 21.01(1)(b) is not satisfied "if the pleading simply discloses a 'reasonable cause of action' by the representative plaintiff against only one defendant and then puts forward a similar claim by a speculative group of putative class members against the other defendants." ${ }^{60}$ Cumming J. explained that rule

Ibid. at 607.

"The claim refers to 'fire safe' cigarettes as those which have 'a reduced propensity for igniting upholstered furniture and mattress fires"' (ibid. at 608).

Supreme Court Rules, B.C. Reg. 221/90, r. 19(24).

Section 5(1)(a) of the Ontario Act, supra note 44 imposes the certification requirement that the pleadings of the representative plaintiff "disclose a cause of action."

Ragoonanan, supra note 27 at 615.

Ibid. at 616 . 
21.01(1)(b) motions take place prior to certification hearings at a time where the class representative is the only plaintiff party to the proceedings. In relation to the class action before him, he noted that there could be no certainty that any of the class members had a cause of action against RBH and JTI-M.

Emphasis was also placed by the Court on the need to ensure that a defendant is not made "subject to a speculative claim which presumes that one or more unknown persons possibly has a cause of action. It would be wrong to put a defendant to the expense of the litigation process if there is no reasonable cause of action against that defendant on the face of the pleading." consistent with the underlying policy goals of the class action device as it would not inhibit multiple defendant class actions "when there is a generic product (or generic defect) in issue, so long as the pleading discloses a reasonable cause of action against each defendant by a representative plaintiff." ${ }^{\prime 62}$

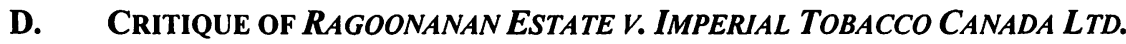

Ragoonanan is unsatisfactory for a number of reasons. The narrow interpretation of $r$. 21.01(1)(b) is inconsistent with the need, recognized by Cumming J. himself, to ensure that r. 21.01(1)(b) is interpreted so as to be consistent with the class action regime governed by the Ontario Act. $^{63}$ This inconsistency may be illustrated with a simple example: assume that two multiple defendant class actions, class action $A$ and class action B, are initiated in which a single representative plaintiff does not have a personal cause of action against every defendant. Also assume that in both actions the defendants against whom the class representatives make no personal claim wish to rely on this fact to have the proceedings against them dismissed. In class action $A$, this submission is advanced by the defendants in the context of a r. 21.01(1)(b) motion. In class action B, the defendants use this line of reasoning as part of their opposition to the certification of the proceedings against them as class proceedings.

It would appear that the submissions of the defendants would be successful in class action A, given the Ragoonanan construction of r.21.01(1)(b), whereas the argument in class action $B$ would likely fail and proceedings would continue against all the defendants because of the more liberal construction accorded to s. 5(1)(a) vis-à-vis r. 21.01(1)(b). It is difficult to comprehend what benefits flow to our legal system or society when two similar proceedings are determined differently by the courts, with the opposite outcomes solely attributable to the differing procedural steps followed by the various defendants in putting forward arguments based on identical legal considerations.

Ibid. Broadly similar concerns were expressed in the U.S. case of Taliaferro v. State Council of Higher Education, 372 F.Supp. 1378 at 1388 (E.D. Va. 1974):

Members of the defendant class who have had no contact with the named plaintiffs run the risk of having to submit to extensive discovery without any specific factual claim having been made against them, and members of the plaintiff class become involved in the necessarily antagonistic position of litigation with their employers against whom neither they nor their 'representatives' have alleged specific improper conduct. 
The comments made by an Australian judge, Young C.J., are apposite here:

The ordinary rules cannot be applied to a representative proceeding without adaption. In my view the Court must be careful to ensure that the Rules of Court are adapted as necessary, and must not allow their use to impede the proper resolution of the proceeding. In a representative proceeding I would be prepared to disregard or adapt any Rule the application of which did not produce a just or convenient result. ${ }^{64}$

It is also important to bear in mind that the concerns expressed by Cumming J. regarding the unfairness of a defendant being embroiled in class proceedings without any certainty that there is a valid cause of action could have been satisfactorily addressed without dismissing the class proceedings against the second and third defendants. In fact, the Court could have postponed a decision on the rule 21.01(1)(b) motion in order to give the representative plaintiff the opportunity to provide the Court with details as to the class members who were making direct claims against such defendants. This strategy would have addressed the concerns of the Court and been in accordance with the access to justice philosophy underpinning class actions, unlike the Court's proposal that those who had a personal claim against RBH and JTI-M commence a separate class proceeding, then request an order for the joinder of the new proceedings with the existing proceedings. ${ }^{65}$

A similar inconsistency with the policy goals of class actions was displayed by the decision of the Ontario Court of Appeal in Stone v. Wellington (County) Board of Education, ${ }^{66}$ a case greatly relied upon by the Court in Ragoonanan. In Stone, the Court upheld the dismissal of a class proceeding where the named plaintiff no longer had a claim against the defendants due to the expiry of a limitation period. Ragoonanan and Stone illustrate the type of problems that are created by the sole focus on the class representatives and their claims that is mandated by the open door theory. As was persuasively argued by an American commentator,

[t]he class representative is, in large part, simply a throwback to the traditional two-party model of litigation. The class representative, as the named plaintiff, makes the class action resemble the traditional lawsuit with which we are comfortable and familiar. When we look to the class representative to satisfy standing and jurisdictional requirements, we are asking the representative to do what the traditional party in the nonclass lawsuit must do. While this approach in some sense may make us feel comfortable, we should ask ourselves whether we are not simply trying to force the class action into a mold in which it will never fit. ${ }^{67}$

${ }_{64}$ Zentahope Pty. Ltd. v. Toycorp Ltd. (14 June 1991) (Vic. S.C.) at 5, Young C.J. [unreported].

is Ragoonanan, supra note 27 at 616.

s. (1999) 29 C.P.C. (4th) 320.

67 Jean Wegman Burns, "Decorative Figureheads: Eliminating Class Representatives in Class Actions" (1990) 42 Hastings L.J. 165 at 186-87. See also Kane, supra note 13 at 83, who noted that "federal courts continue to utilize the same standing requirements for both individual and class suits, with very little consideration of whether the doctrine serves a functional purpose when applied to federal class actions, or whether standing to sue and standing to act as a class representative should be two separate concepts." 
Unfortunately, Ragoonanan has been applied by Ontario courts, ${ }^{68}$ including the Court of Appeal in its September 2002 decision in Hughes. ${ }^{69}$ In Hughes, a class proceeding was brought against a number of manufacturers of smoke alarms. The Ontario Court of Appeal held that the class representative

cannot claim to have a reasonable cause of action against the defendant manufacturers who did not manufacture the smoke alarm he purchased. He cannot resist a rule 21.01(1)(b) motion by alleging that some as yet unknown members of a proposed class may have a cause of action against these other manufacturers if the class action is certified. ${ }^{70}$

The Court also indicated that "British Columbia courts may be more willing to let a proposed class action proceed against defendants against whom no representative plaintiff has a claim. To the extent that these British Columbia decisions conflict with the Ontario cases of Boulanger and Ragoonanan, I prefer the reasoning in the Ontario cases."

\section{Multiple Defendant Class ACtions in BRitish Columbia}

\section{A. The Class ProceEdings ACT}

A proceeding may be certified as a class proceeding under s. 4(1) of the Class Proceedings $\mathrm{Act}^{72}$ if the following conditions have been met:

(a) the pleadings disclose a cause of action;

(b) there is an identifiable class ${ }^{73}$ of 2 or more persons [that would be represented by the representative plaintiff];

(c) the claims of the class members raise common issues, whether or not those common issues predominate over issues affecting only individual members;

(d) a class proceeding would be the preferable procedure for the resolution of the common issues; [and]

See e.g. Pearson v. Inco Ltd. (2002), 27 C.P.C. (5th) 171 at para. 84, Nordheimer J. (Ont. Sup. Ct.); and Boulanger v. Johnson \& Johnson (2002), 14 C.C.L.T. (3d) 233 at para. 21, Nordheimer J. [Boulanger]: "for each defendant who is named in a class action there must be a representative plaintiff who has a valid cause of action against that defendant." But see, Lupsor Estate v. Middlesex Mutual Insurance Co., [2003] O.J. No. 1038 (Ont. Sup. Ct.) (QL), where Haines J. held that it was not necessary for a plaintiff in an intended class action to have a cause of action against each member of a putative defendant class in order to proceed with a motion for certification and the appointment of a representative defendant.

Hughes, supra note 2.

Ibid. at para. 16.

Ibid. at para. 17.

R.S.B.C. 1996, c. 50 [B.C. Act].

See Western Canadian Shopping Centres Inc. v. Bennett Jones Verchere, [2001] 2 S.C.R. 534, (2001), 201 D.L.R. (4th) 385 at 401, McLachlin C.J.C. [Western cited to D.L.R.]:

[T] he class must be capable of clear definition. Class definition is critical because it identifies the individuals entitled to notice, entitled to relief (if relief is awarded), and bound by the judgment. It is essential, therefore, that the class be defined clearly at the outset of the litigation. The definition should state objective criteria by which members of the class can be identified. 
(e) there is a representative plaintiff who (i) would fairly and adequately represent the interests of the class, (ii) has produced a plan for the proceeding that sets out a workable method of advancing the proceeding on behalf of the class and of notifying class members of the proceeding, and (iii) does not have, on the common issues [for the class], an interest that is in conflict with the interests of other class members. $^{74}$

The B.C. Act lists five factors that the Court must consider in determining whether the class action device is the preferable procedure for resolving the common issues:

(a) whether questions of fact or law common to the members of the class predominate over any questions affecting only individual members; (b) whether a significant number of the members of the class have a valid interest in individually controlling the prosecution of separate actions; (c) whether the class proceeding would involve claims that are or have been the subject of any other proceedings; (d) whether other means of resolving the claims are less practical or less efficient; and (e) whether the administration of the proceeding would create greater difficulties than those likely to be experienced if relief were sought by other means. ${ }^{75}$

\section{B. Minimal Restrictions on Multiple Defendant Class ACtions}

Only eight months after the B.C. Act came into force, Mackenzie J. of the Supreme Court of British Columbia was asked to consider the rules governing multiple defendant class actions brought under it in Harrington $v$. Dow Corning. ${ }^{76}$ In Harrington, a class action was brought by a single representative plaintiff against 16 defendants who were manufacturers and distributors of silicone breast implants. The action was certified as a class action even though the representative plaintiff had a personal claim against only five of the 16 defendants. Harrington displays a judicial rejection of the need to impose on class representatives either the requirement that: (a) a class representative needs to have a cause of action against every defendant, or (b) for each defendant there needs to be a class representative with a cause of action against that defendant.

In November 1997, the class proceedings in Campbell $^{77}$ provided the British Columbia Court of Appeal with its first opportunity to consider standing and multiple defendant class actions with respect to the B.C. Act. In Campbell, the defendants lodged an appeal from the decision of the trial judge to certify the action as a class proceeding and to appoint Campbell and Isherwood as the class representatives. The named plaintiffs were acting on behalf of the owners of radiant ceiling heating panels (RCHPs) produced by several manufacturers. Each defendant was the subject of a cause of action by at least one of the named plaintiffs. However, neither of the two named plaintiffs could be said to have a personal cause of action against each of the defendants. The defendants relied upon the latter fact, among other things, to persuade the Court that the proceeding should not have been certified. The Court of Appeal held that "there is no requirement that there be a representative plaintiff with a cause 
of action against every defendant; the legislation simply requires that there be a cause of action. ${ }^{178}$ The Court also made the following important observations concerning Harrington:

\footnotetext{
Justice Mackenzie ... went on to certify the class action [in Harrington] without requiring a representative plaintiff for each manufacturer irrespective of the fact that there were sixteen defendants and the representative plaintiff had a cause of action against only five of them. This indicates, and I agree, that it is not necessary that a representative plaintiff have a cause of action against each defendant in order to certify a proceeding as a class proceeding. ${ }^{79}$
}

That approach was confirmed by the Court of Appeal in Furlanv. Shell Oil, ${ }^{80}$ a case which raised "the issue of the relationship of pleadings and evidence on an application for a declaration that the court has no jurisdiction over foreign defendants served ex juris under r. 13 of the Rules of Court." ${ }^{\prime 81}$ It was an action in tort for damages caused by allegedly defective polybutylene plumbing systems. The plaintiffs proposed to have the action certified as class proceedings under the B.C. Act. They also served the originating process ex juris on the defendants without leave on the ground that the tort was committed in British Columbia. The defendants applied to have the service ex juris set aside on the ground that the plaintiffs had to establish a good arguable case by adducing evidence rather than by relying on the pleadings. In holding that the chambers judge was right to refuse to set aside service of the defendants ex juris, the Court of Appeal made several pertinent comments:

Du Pont contends that at least before certification the references in the amended statement of claim to "the Plaintiffs and the Class" are not proper pleading and the respondents on this application must link causation of Du Pont resin to individual plaintiffs and not intended class members generally. In my opinion, that is too narrow a view of the pleadings in proceedings intended to be pursued under the Class Proceedings Act. On this application, causation should be considered in the context of the proposed class generally and not the individually named plaintiffs. ${ }^{82}$

Campbell and Furlan, together with the Court of Appeal's subsequent dismissal of an appeal from the certification order $^{83}$ given by Mackenzie J. in Harrington, unambiguously demonstrate a judicial rejection in British Columbia of the requirement, embraced in Ontario, that for each defendant there must be a representative plaintiff with a cause of action against that defendant.

In British Columbia, 'the 'cause of action' criterion for certification is met when the representative plaintiff has a cause of action against at least one named defendant, there are putative class members with a cause of action against the other defendants, and an allegedly defective generic product is in issue that raises common issues of fact or law." ${ }^{\prime 84}$

[2000] 7 W.W.R. 433, Mackenzie J. [Furlan].

Ibid. at 434 .

Ibid. at 441 .

Harrington v. Dow Corning Corp., [2000] 11 W.W.R. 201 (B.C.C.A.) [Harrington Appeal].

Ragoonanan, supra note 27 at 614. 


\section{ANALYSIS OF CAMPBELL V. FLEXWATT CORP., HARRINGTON V. DOW CORNING, AND FURLAN V. SHELL OIL}

Campbell, Harrington, and Furlan reflect an approach to standing under the B.C. Act that to some extent embraces the class standing theory mentioned above. ${ }^{85}$ The British Columbia Court of Appeal may be said to have recognized that

in class actions the requirement that the named representative plaintiff have a personal stake in the form of a direct injury is less compelling on jurisdictional grounds. In such cases, the class itself is the real party in interest. If the unnamed members of the class satisfy the requirements of standing, then a real controversy exists between the class and the defendant, which should be sufficient to invoke the court's jurisdiction.... In more traditional representative actions involving fiduciaries, trustees or "next friends," the stake of the person or entity represented determines standing, not the stake of the representative.... Logically, jurisdictional requirements imposed upon class representatives should be no more onerous. ${ }^{86}$

Campbell, Harrington and Furlan may also be viewed from another perspective. The Court in these cases was not faced with plaintiffs who (a) had not suffered an injury-in-fact (that is, an invasion of a legally protected interest that was concrete and actual), (b) could not demonstrate that a causal connection existed between the injury and the conduct of which the plaintiffs complained, and (c) could not demonstrate the likelihood, and not merely the speculative possibility, that the injury would be redressed by the requested relief. ${ }^{87}$ They were instead faced with plaintiffs who sought to provide court access to persons who were harmed by the same defendants as those that injured the plaintiffs and persons who were harmed by other defendants than those that injured the plaintiffs in similar circumstances to those surrounding the harm suffered by the plaintiffs.

The fundamental difference between the class proceedings studied in this article and attempts to initiate litigation by those who have suffered no injuries at the hands of any of the intended defendants of a given action becomes apparent when one explores the major reasons for the traditional standing requirement. Generally speaking, the requirement stipulates that

8s Total adherence to the class standing theory would be achieved if proceedings commenced against multiple defendants by class representatives who had no personal cause of action against any of the defendants were certified under the B.C. Act. [emphasis in original].

87 According to the U.S. Supreme Court in Lujan v. Defenders of Wildlife, 504 U.S. 555 at 560-61 (1992) [Lujan], the scenarios mentioned above are the three requirements that must be satisfied by a potential plaintiff in order to establish standing to sue a defendant. 
a plaintiff may not sue a defendant who has caused him/her no legal injury. ${ }^{88}$ The U.S. Supreme Court explained one rationale ${ }^{89}$ for this approach, noting that

[t]he question of standing is related only to whether the dispute sought to be adjudicated will be presented in an adversary context and in a form historically viewed as capable of judicial resolution. It is for that reason that the emphasis in standing problems is on whether the party invoking federal court jurisdiction has "a personal stake in the outcome of the controversy", Baker v. Carr, [369 US] at 204, and whether the dispute touches upon "the legal relations of parties having adverse legal interests", Aetna Life Insurance Co $v$. Howorth, [300 US] at 240-241..$^{90}$

In multiple defendant class actions brought by those who have been harmed by some of the defendants, the traditional concerns expressed above are clearly not applicable, as the legal dispute that results in the group litigation "will be presented in an adversary context and in a form historically viewed as capable of judicial resolution." 91

Another reason that has been advanced for restricting standing to sue is "the fear that without such restrictions there would be a multiplicity of actions. This fear was one of the principal reasons for restricting an individual's rights to sue in respect of a public nuisance." 92 Allowing class actions to be prosecuted against multiple defendants, even where

This description is totally accurate with respect to the American position: see text accompanying notes 123-25 below. In Australia, however, statutory standing is generally sufficient to overcome the lack of a direct or special interest in the subject-matter of the proceedings. See Truth About Motorways Pty. Ltd. v. Macquarie Infrastructure Investment Management Ltd. (2000), 169 A.L.R. 616. In Canada, the Supreme Court has held that "to establish status as a plaintiff in a suit seeking a declaration that legislation is invalid, if there is a serious issue as to its invalidity, a person need only show that he is affected by it directly or that he has a genuine interest a citizen in the validity of the legislation and that there is no other reasonable and effective manner in which the issue may be brought before the Court" (Minister of Justice of Canada v. Borowski, [1981] 2 S.C.R. 575 at 598, Martland J.).

The Supreme Court of Canada has summarized the traditional concerns about widening access to the courts as "the concern about the allocation of scarce judicial resources and the need to screen out the mere busybody; the concern that in the determination of issues the courts should have the benefit of the contending points of view of those most directly affected by them; and the concern about the proper role of the courts and their constitutional relationship to the other branches of government" (Finlay $v$. Canada (Minister of Finance), [1986] 2 S.C.R. 607 at 631, Le Dain J.).

Flast v. Cohen, 392 U.S. 83 at 101 (1968) [Flast]. See also Simon v. Eastern Kentucky Welfare Rights Organisation, 426 U.S. 26 at 38, n. 16 (1976):

this Court often has noted that the focus upon the plaintiff's stake in the outcome of the issue he seeks to have adjudicated serves a separate and equally important function bearing upon the nature of the judicial process. As stated in Baker v. Carr, 369 U.S. 186 at 204 (1962), a significant personal stake serves "to assure that concrete adverseness which sharpens the presentation of issues upon which the court so largely depends for illumination of difficult ... questions."

Flast, ibid. at 101 ; Kane, supra note 13 at 99 . Kane also noted that "[i]n those instances the court need not worry that the issues lack concreteness or that the parties are not adverse, since those requirements are clearly satisfied by the representative's individual claim" (ibid.). See also "Defendant Class Actions", Note (1978) 91 Harvard L. Rev. 630 at 639, n. 48; and Streich v. American Family Mutual Insurance, 399 N.W. 2d 210 at 216 (Minn. App. 1987) [Streich]: "class suits are more manageable and the judicial process is better served when courts are not available to plaintiffs who have suffered no harm at the hands of the defendants against whom they complain."

LRCBC, supra note 7 at 31. See also Canadian Council of Churches v. The Queen \& Others, [1992] I S.C.R. 236 at 252, Cory J.:

[i]t is essential that a balance be struck between ensuring access to the courts and preserving judicial resources. It would be disastrous if the courts were allowed to become hopelessly 
the representative plaintiffs do not have personal causes of action against all the defendants, furthers, rather than hinders, attainment of the desirable goal of conserving scarce judicial resources. It is, in fact, the restrictive judicial approach to locus standi in multiple defendant class actions, such as that exhibited in Australia and Ontario, that generates more litigation as it necessarily results in the commencement of additional class or individual proceedings. ${ }^{93}$

As explained by the Law Reform Commission of British Columbia, a third reason "for restrictions on an individual's standing, is the desire to eliminate 'busybodies' from cluttering up the judicial system." 94 Whether or not this generally constitutes a persuasive line of reasoning, ${ }^{95}$ it can hardly have any relevance to the type of class proceedings reviewed here, given that plaintiffs who allege that they have suffered legally recognized harm at the hands of some of the defendants may not reasonably be described as "busybodies." Therefore, the imposition of a total ban on the type of class proceedings reviewed in the present article would be difficult to reconcile with the recognized "role of courts [which is] to provide relief to claimants, in individual or class actions, who have suffered, or will imminently suffer, actual harm." $" 96$

It should be apparent that, from a conceptual perspective, one need not necessarily embrace the class standing theory in order to recognize the crucial difference between multiple defendant class actions commenced by representative plaintiffs who do not have personal claims against all of the defendants and proceedings initiated by those who have no personal stake in the outcome of the litigation. As was pointed out by the U.S. Court of Appeals for the Seventh Circuit, "this is not a case where the named plaintiff is trying to piggy-back on the injuries of the unnamed class members," 97 and further, by the District Court for the Southern District of New York,

many of the prudential concerns traditionally associated with the standing doctrine are met as long as at least one plaintiff who is clearly an injured party sues at least one defendant who has caused him injury. As critics of a high standing threshold in class actions have pointed out, the Rule 23 requirements of adequacy of

overburned as a result of the unnecessary proliferation of marginal or redundant suits brought by well-meaning organizations pursuing their own particular cases certain in the knowledge that their cause is all important.

See e.g. Philip Morris, supra note 1 at 514:

it follows that s. $33 \mathrm{C}(1)(\mathrm{a})$ is not satisfied if some applicants and group members have claims against one respondent (or group of respondents) while other applicants and group members have claims against another respondent (or group of respondents).... Of course, if there are two sets of claims against two sets of respondents, it may well be that each can be the subject of representative proceedings. It may even be that directions can be made for them to be heard together: Ryan v. Great Lakes Council (1997), 149 A.L.R. 45 at 48, Wilcox J. But they cannot both be the subject of the same representative proceedings. LRCBC, supra note 7 at 31 .

A number of commentators have cogently rejected the general validity of this argument. For instance, Kenneth E. Scott, "Standing in the Supreme Court - A Functional Analysis" (1973) 86 Harvard L. Rev. 645 at 674.

Lewis v. Casey, 518 U.S. 343 at 349 (1996).

Payton v. County of Kane, 308 F.3d 673 at 682 (7th Cir. 2002) [Payton] 
representation and typicality of claims" ensure a vigorous and focused litigation of the common issues even though the named plaintiff may not have a cause of action against each named defendant. ${ }^{99}$

Consequently, it is submitted that courts in British Columbia have adopted the correct approach by dealing with multiple defendant class proceedings within the class action framework created by the B.C. Act and by refusing to erect significant barriers to the commencement of class proceedings by the application of traditional standing requirements.

The experience in British Columbia demonstrates that treating the rules governing standing as irrelevant to multiple defendant class actions initiated by those who have individual standing to sue only some of the defendants need not result in proceedings which are inappropriate or burdensome. This desirable scenario may be achieved as long as courts interpret and apply the provisions governing class actions in a way that seeks to ensure that class members and defendants are treated fairly and that the policy goals of class actions, such as access to justice, are fulfilled. Such a judicial approach is recommended in relation to all class proceedings, not only those involving multiple defendants. ${ }^{100}$

An excellent illustration of the adoption by British Columbia courts of the approach advocated in the preceding paragraph is provided by the way in which the Court of Appeal has applied to multiple defendant class actions the certification requirement that the claims of the class members raise common issues. ${ }^{101}$ In Harrington Appeal, Huddart J.A., speaking for the majority, explained that

\footnotetext{
"common" means that the resolution of the point in question must be applicable to all who are to be bound by it. I agree with the appellants that to be applicable to all parties, the answer to the question must, at least, be capable of extrapolation to each member of the class or subclass on whose behalf the trial of the common issues is certified for trial by a class proceeding. As the appellants note, this requirement will, of necessity, require that the answer be capable of extrapolation to all defendants who will be bound by it. $^{102}$
}

At the same time, the Court of Appeal recognized the importance of not applying this prerequisite in a manner that would render the B.C. Act regime largely unavailable to legal disputes involving multiple defendants:

Typicality is the label commonly used to describe one of the four threshold requirements applicable to class actions in the United States. This requirement is not part of the B.C. Act nor the Ontario Act. Akerman v. Oryx Communications Inc., 609 F.Supp. 363 at 375 (S.D.N.Y. 1984) [Akerman].

100 See e.g. Lord Chancellor's Department, Representative Claims: Proposed New Procedures (Consultation Paper) (London: February 2001) at para. 18, where attention was drawn to the need to "achieve a balance between increasing access to justice and avoiding inappropriate and burdensome litigation."

102 Supra note 83 at 217 . In that case, the common issue was whether silicone gel breast implants were reasonably fit for their intended purpose. Similarly, the Federal Court of Australia has held that $\mathbf{s}$. $33 \mathrm{C}(1)$ (c) of Part IVA, supra note 14, requires that the claims of all the named plaintiffs and class members against all the defendants must give rise to at least one substantial common issue of fact or law. See Philip Morris, supra note 1 at 524; Hunter Valley, supra note 33 at paras. 58-60; and King, supra note 39 at para. 13. 
When examining the existence of common issues it is important to understand that the common issues do not have to be issues which are determinative of liability; they need only be issues of fact or law that move the litigation forward. The resolution of a common issue does not have to be, in and of itself, sufficient to support relief. To require every common issue to be determinative of liability for every plaintiff and every defendant would make class proceedings with more than one defendant virtually impossible. ${ }^{103}$

An essential aspect of contemporary class action regimes is that courts are seen as having a managerial role. ${ }^{104}$ The following comments made by an Ontario judge, Winkler J., in relation to the Ontario Act are equally applicable to the B.C. Act:

In a more general sense, the feature which most distinguishes a class proceeding from a traditional proceeding is the degree and extent of case management and supervision exercised by the court... These are to ensure that the interests of absent class members are protected and that the efficiencies central to the purpose of the Act are indeed realised. The Act is replete with provisions or "judicial tools", which enable the court to assume a pro-active and continuing role in the litigation as it progresses to the final determination. ${ }^{105}$

\section{The Alberta Law Reform Institute summarized the major managerial powers conferred upon} Canadian courts presiding over class proceedings as follows:

deciding on certification; making sure that the class is properly represented; scrutinizing the plan for the class proceeding; overseeing the conduct of the proceeding; tailoring the rules as necessary to accommodate the class proceeding; playing an active role in managing the case; approving settlements and the class lawyers' fees and disbursements; and generally protecting the interests of the "absent" class members. ${ }^{106}$

In the context of multiple defendant class actions, two judicial tools or powers granted by class action regimes would appear to be of particular importance: the ability to divide the

Campbell, supra note 3 at para. 53. Further, at para. 62, the Court states that, "in my view, the threshold primary question as to whether the RCHPs were fit for their intended purpose is common to all named defendants. If the RCHPs are found to be fit for the purpose for which they were intended then the majority of other secondary issues become moot. If, however, the RCHPs are found unfit, then the other secondary issues will have to be addressed and any need for sub-classes can be addressed at that time. Regardless of whether the RCHPS are found to be fit or unfit - the answer will move the case forward."

Hoffmann-La Roche Inc. v. Sperling, 110 S. Ct. 482 at 486 (1989). See also In re Air Crash Disaster at Florida Everglades, 549 F.2d 1006 at 1012, n. 8 (5th Cir. 1977): "in class actions we recognize, indeed insist upon, the court's participation as the manager of the case"; Federal Judicial Center, Manual for Complex Litigation, 3d ed., (United States of America: Federal Judicial Center, 1995) at 211: "by its nature, litigation in which claims are made by or against a class tends to be complex and require judicial management. Particularly because such litigation imposes unique responsibilities on the court, as well as on counsel, it calls for closer judicial oversight than other types of litigation. The potential for actions, by counsel or parties, that will deliberately or inadvertently result in prejudice to litigants is great"; and Gates v. Cook, 234 F.3d 221 at 227 (5th Cir. 2000). v. Canadian Red Cross Society (1997), 36 B.C.L.R. (3d) 350 at 364, Smith J.; and Zarate v. Younglove, 86 F.R.D. 80 at 93 (C.D. Cal. 1980): "the rules explicitly authorize judicial involvement that would, in any other setting, be antithetical to the well-established norms of judicial passivity." 
class members into subclasses, ${ }^{107}$ and the power to ensure that the class is properly represented. In that regard, s. $6(1)$ of the B.C. Act provides that

if a class includes a subclass whose members have claims that raise common issues not shared by all the class members so that, in the opinion of the court, the protection of the interests of the subclass members requires that they be separately represented, the court must not certify the proceeding as a class proceeding unless there is, in addition to the representative plaintiff for the class, a representative plaintiff who ... would fairly and adequately represent the interests of the subclass. ${ }^{108}$

British Columbia courts have displayed a willingness to create subclasses whenever such a step is required to ensure the fair and efficient prosecution of multiple defendant class proceedings. ${ }^{109}$

As indicated above, one of the prerequisites for certification is that there be a representative plaintiff who would fairly and adequately represent the interests of the class. ${ }^{110}$ As was explained by the Manitoba Law Reform Commission:

in order to certify a proceeding the court must be satisfied that the proposed representative plaintiff will adequately represent the class. If this criterion is not met at any point during the proceedings, the court may, on motion by a party or a class member or on its own motion, amend the certification order. Although there is no specific or express power to replace the representative party, it is implicit in the scheme of the legislation that a representative party may be replaced if necessary. ${ }^{11}$

To the author's knowledge, such a power has not been exercised by British Columbia courts with respect to class representatives who lacked individual standing in relation to some of the defendants facing a proceeding commenced pursuant to the B.C. Act. This suggests that those members of the class whose injuries were inflicted by defendants other than those who

Report of the Attorney General's Advisory Committee on Class Action Reform (Toronto: Ministry of the Attorney General, 1990) at 33:

sub-classing is a process by which the larger class is divided into more distinct and representative groups. A sub-class will have an issue of law or fact common to itself and therefore requires separate representation in order to protect interests that it has separate from the larger class. Inherent in sub-classing is the need to ensure that the sub-class is not prejudiced by being in conflict with the larger classes' interest.

109) See e.g. Collette v. Great Pacific Management Co., 2001 B.C.D. Civ. J. 1100 at para. 140, Macaulay J.; Pearson v. Boliden Ltd., 2001 B.C.D. Civ. J. 2453 at para. 71, Burnyeat J.; and Campbell, supra note 3 at paras. $42,46$.

According to the Supreme Court of Canada in Western, supra note 73 at 402 ,

in assessing whether the proposed representative is adequate, the court may look to the motivation of the representative, the competence of the representative's counsel, and the capacity of the representative to bear any costs that may be incurred by the representative in particular (as opposed to by counsel or by the class members generally). The proposed representative need not be 'typical' of the class, nor the 'best' possible representative. The court should be satisfied, however, that the proposed representative will vigorously and capably prosecute the interests of the class.

Manitoba Law Reform Commission, Class Proceedings, Report \# 100 (Winnipeg: Manitoba Law Reform Commission, 1999) at 104. In Australia, Part IVA, supra note 14, s. 33T expressly provides that "if, on an application by a group member, it appears to the Court that a representative party is not able adequately to represent the interests of the group members, the Court may substitute another group member as representative party and may make such orders as it thinks fit." 
harmed the representative plaintiffs will not necessarily be inadequately represented by such plaintiffs. ${ }^{112}$ Comments made by the U.S. Supreme Court in another context are relevant in this regard:

In Sosna v. lowa it was recognized that a named plaintiff whose claim on the merits expires after class certification may still adequately represent the class. Implicit in that decision was the determination that vigorous advocacy can be assured through means other than the traditional requirement of a "personal stake in the outcome." 113

Finally, it should be noted that the judicial approach followed in Campbell, Furlan, and Harrington is consistent with s. 2(4) of the B.C. Act, although no reliance was placed by the Court of Appeal on that provision. Section 2(4) authorizes the Court presiding over a class proceeding to "certify a person who is not a member of the class as the representative plaintiff for the class proceeding only if it is necessary to do so in order to avoid a substantial injustice to the class."

\section{Multiple Defendant Class ACtions in the United States}

\section{A. Rule 23 of the United States Federal Rules of CiVIL Procedure}

Under r. 23(a) of the Federal Rules of Civil Procedure, ${ }^{115}$ plaintiffs must satisfy all of the following requirements before the class can be certified:

(1) [numerosity] the class [must be] so numerous that joinder of all members is impracticable, (2) [commonality] there [must be] questions of law or fact common to the class, (3) [typicality] the claims or defences of the representative parties [must be] typical of the claims or defences of the class, and (4)

"Thus, the fact that the representative ... has a claim, but only against one member of the defendant class, does not necessarily mean that he cannot adequately protect the interests of the class members. His competence must be evaluated in light of the various other means at the court's disposal to assure that those interests are safeguarded" (Kane, supra note 13 at 109).

United States Parole Commissioner v. Geraghty, 445 U.S. 388 at 404 (1980) [Geraghty]. The traditional line of reasoning to support a ban on class representatives who have no personal stake in the outcome of the litigation is that "self-interest will help to ensure adequate representation for the class members" (Ontario Law Reform Commission, Report on Class Actions Report No. 48 (Ontario: Ministry of the Attorney General, 1982) at 349). See also S.R. Kane, "Representation of Class Actions: Is Personal Interest Replacing Personal Stake?" (1981) Ariz. St. L.J. 1007 at 1025; M.G. Carroll, "The Personal Stake Requirement in Federal Class Action Litigation" (1981) 33 Baylor L. Rev. 337 at 337; D.J. Steinger, "Class Actions: Defining the Typical and Representative Plaintiff under Subsections (a)(3) and (4) of Federal Rule 23" (1972) 46 B.U.L. Rev. 406 at 414; Frost v. Weinberger 515 F.2d 57 at 64 (2nd Cir. 1975); and Adolf Homburger, "Private Suits in the Public Interest in the United States of America" (1974) 23 Buff. L. Rev. 343 at 362.

For a persuasive rejection of this line of reasoning, see South African Law Commission, The Recognition of Class Actions and Public Interest Actions in South African Law, Project 88 Report (South Africa: South African Law Commission, August 1998) at para. 5.5.5. See also John C. Coffee, Jr., "Class Action Accountability: Reconciling Exit, Voice, and Loyalty in Representative Litigation" (2000) 100 Colum. L. Rev. 370 at 375.

114 B.C. Act, supra note 72 . Strangely, British Columbia courts have rarely used the power conferred by this provision. See Vince Morabito, "Ideological Plaintiffs and Class Actions - An Australian Perspective" (2001) 34 U.B.C. L. Rev. 459 at 510-11. 
[adequacy of representation] the representative parties must fairly and adequately protect the interests of the class. $^{116}$

In addition, plaintiffs must satisfy one of the alternative conditions found in r. 23(b). Rule 23(b) creates three different types of class actions. The first, regulated by r. 23(b)(1), deals with situations where, in the absence of a class action, separate proceedings would "...either establish incompatible standards of conduct for the party opposing the class, or would practically prejudice the interests of class members who are not made parties." "17 The second category of class actions, governed by r. 23(b)(2), deals with cases where "the party opposing the class has acted or refused to act on grounds generally applicable to the class, thereby making appropriate final injunctive relief or corresponding declaratory relief with respect to the class as a whole."

Rule 23(b)(3) class actions are cases where common questions of law or fact "predominate over any questions affecting only individual [class] members, and that a class action is superior to other available methods for the fair and efficient adjudication of the controversy." ${ }^{119}$ Rule 23(b)(3) enumerates four factors to be considered in authorizing a class proceeding under that subsection:

(A) the interest of members of the class in individually controlling the prosecution or defense of separate actions;

(B) the extent and nature of any litigation concerning the controversy already commenced by or against members of the class;

C) the desirability or undesirability of concentrating the litigation of the claims in the particular forum;

(D) the difficulties likely to be encountered in the management of a class action. ${ }^{120}$

The right to opt out is automatically available to class members in relation to only one of the three types of class actions envisaged by r. 23, namely, class actions governed by $r$. $23(\mathrm{~b})(3)^{121}$

Another relevant provision is r. 23(d), which provides that "in the conduct of actions to which this rule applies, the court may make appropriate orders: (1) determining the course of proceedings ... (3) imposing conditions on the representative parties or on intervenors; ... (5) dealing with similar procedural matters." 122

121 Ibid. Rule 23(c)(2)(A) provides that in a 23(b)(3) class action, individual notice must be given to each identifiable class member informing him/her, among other things, that "the court will exclude him from 


\section{B. ARticle III OF The U.S. CONSTItution}

In the United States, the concept of standing has a constitutional dimension due to the directive contained in Article III of the U.S. Constitution, which provides that federal judicial power shall extend only to "cases" and "controversies." 23

The requirement of standing ... has a core component derived directly from the Constitution. A plaintiff must allege personal injury fairly traceable to the defendant's allegedly unlawful conduct and likely to be redressed by the requested relief. ${ }^{124}$

The U.S. Supreme Court has explained the standing threshold for class representatives in a comment which appears to display the Court's clear adherence to the open door theory:

the individual respondents sought to maintain this suit as a class action on behalf of all persons similarly situated. That a suit may be a class action, however, adds nothing to the question of standing, for even named plaintiffs who represent a class "must allege and show that they personally have been injured, not that injury has been suffered by other, unidentified members of the class to which they belong and which they purport to represent." 125

However, a somewhat different picture emerges if one considers a number of the Court's other decisions. For instance, in Sosna $v$. Iowa, ${ }^{126}$ the Court held that mootness of the named plaintiff's individual claim after a class has been certified does not render the action itself moot. As the U.S. Supreme Court subsequently explained,

the claims in Sosna also fit the traditional category of actions that are deemed not moot despite the litigant's loss of personal stake, that is, those "capable of repetition, yet evading review"... In Franks $v$. Bowman Transportation Co. ..., however, the Court held that the class-action aspect of the mootness doctrine does not depend on the class claim's being so inherently transitory that it meets the "capable of repetition, yet evading review" standard. $^{127}$

Also in Geraghty, the Court extended this principle by holding that a class action does not become moot upon expiration of the class representative's substantive claim even when certification was denied by the Court. ${ }^{128}$ Consequently, according to the U.S. Supreme Court,

U.S. Const. art. III, $\$ 2$ [Article III]].

Allen v. Wright, 468 U.S. 737 at 751 (1984), citing Valley Forge Christian College v. Americans United for Separation of Church and State Inc., 454 U.S. 464 at 472 (1982). See also Lujan, supra note 87 at 560-61; Linda R.S. v. Richard D., 410 U.S. 614 at 617 (1973); and McCabe v. Atchison T\& SFR Co., 235 U.S. 151 at 162 (1914): "[i]t is the fact, clearly established, of injury to the complainant not to others - which justifies judicial intervention."

Simon v. Eastern Kentucky Welfare Rights Organization, 426 U.S. 26 at 40, n. 20 (1976), quoting Warth v. Seldin, 422 U.S. 490 at 502 (1975). See also Bailey v. Patterson, 369 U.S. 31 at 32-33 (1962); and $O$ 'Shea v. Littleton, 414 U.S. 488 at 494 (1974).

419 U.S. 393 (1975).

Geraghty, supra note 113 at 398, n. 6.

See also Payton, supra note 97; and Richard K. Greenstein, "Bridging the Mootness Gap in Federal Court Class Actions" (1983) 53 Stan. L. Rev. 897 at 905-906: "if a case or controversy [analysis as in Sosna and Franks] is needed for a federal court constitutionally to exercise jurisdiction [citation omitted], and if class certification is necessary to raise the class claim to case-or-controversy status, then it necessarily follows that the mooting of the class representative's claims prior to certification ends the 
the class representative could continue to argue on appeal for reversal of the Court's denial of class certification despite the mootness of his individual claim. It is therefore not surprising that the Court has been criticized for adopting "two conflicting and irreconcilable approaches ... in resolving class action standing and mootness issues." 129

The uncertainty concerning the precise role that standing rules play in Rule 23 proceedings has increased following comments made by the U.S. Supreme Court in Ortiz v. Fibreboard Corp.: ${ }^{130}$ "The class certification issues are ... 'logically antecedent' to Article III concerns, and themselves pertain to statutory standing, which may properly be treated before Article III standing. Thus the issue about Rule 23 certification should be treated first." ${ }^{\prime 13}$ If the individual standing of the class representative is to be regarded as the determining factor, then the first logical step would be to assess whether the named plaintiff has individual standing. If no standing can be shown by the aspiring class representative, one would never, pursuant to the open door theory, reach the Rule 23 certification issue. This was certainly the approach followed in Weiner v. Bank of King of Prussia, ${ }^{132}$ one of the leading examples of judicial adherence to the open door theory. In Weiner, the representative plaintiff brought a class action against 20 banks. The Court, holding that the plaintiff borrower did not have standing to sue the 19 banks with whom he had no dealings, explained that

the sole issue presently before the Court is whether a plaintiff who alleges a credit transaction with one bank has standing to sue nineteen other banks with which he never dealt... Rather than confront the issue of standing, the plaintiff has attempted to divert the argument to questions of class actions under Rule 23. However, standing and the specific requirements of Rule 23 are separate and distinct issues, and a plaintiff may not use the procedural device of a class action to bootstrap himself into standing he lacks under the express terms of the substantive law. ${ }^{133}$

The Court of Appeals for the Seventh Circuit has attempted to reconcile the decisions of the U.S. Supreme Court on standing in Rule 23 proceedings:

We understand Ortiz to rest on the long-standing rule that, once a class is properly certified, statutory and Article III standing requirements must be assessed with reference to the class as a whole, not simply with reference to the individual named plaintiffs. The certification of a class changes the standing aspects of a suit, because "[a] properly certified class has a legal status separate from and independent of the interest asserted by the named plaintiff." 134

court's article III jurisdiction."

Burns, supra note 67 at 168 .

527 U.S. 815 (1999).

Ibid. at 831 citing Amchem Products v. Windsor, 521 U.S. 591 at 612 (1997).

358 F.Supp 684 (E.D. Pa. 1973) [Weiner].

Ibid. at 705. See also Brown v. Cameron-Brown Co., 92 F.R.D. 32 at 39, n. 6 (E.D. Va. 1981):

"although courts will usually come to the same conclusion through a typicality or standing analysis where the representative is somehow deficient as to standing, it is generally considered to be improper to address what are in fact standing issues during a consideration of class certification"; Chevalier v. Baird Savings Association, 66 F.R.D. 105 at 109 (E.D. Pa. 1975); and Kauffman v. Dreyfus Fund Inc., 434 F.2d 727 at 734 (3rd Cir. 1970).

1.34 Payton, supra note 97 at 680, quoting Whitlock v. Johnson, 153 F.3d 380 at 384 (7th Cir. 1998). However, this interpretation does not explain the outcome in Geraghty, wherein certification was denied. This interpretation of Ortiz was recently provided by the District Court for the District of New Jersey, which held that the principle enunciated in Ortiz 
None of the Rule 23 cases that reached the U.S. Supreme Court on standing matters raised the issue explored in this article, as in each case the representative plaintiffs lacked individual standing to sue any of the defendants. ${ }^{135}$ The leading judicial pronouncement on standing to sue multiple defendants in a Rule 23 proceeding is the 1973 decision of the Court of Appeals for the Ninth Circuit in La Mar. ${ }^{136}$

\section{LA MAR V. H\& B NOVELTY \& LOAN}

La Mar was a consolidated appeal of two separate actions. The first case involved a truthin-lending action brought on behalf of an estimated 33,000 customers of all pawnbrokers licensed to do business in Oregon. The representative plaintiff had dealings with only one pawnbroker. This action was certified by the District Court as a plaintiff class action. The second case was a class action brought by a passenger of Trans World Airlines and Piedmont Aviation Corp. that challenged the fare construction system employed by the defendants and six other domestic airlines. The Court dismissed the proceedings against the other airlines because those defendants had not caused any injuries to the class representative.

The Court of Appeal for the Ninth Circuit affirmed the District Court's ruling with respect to the airlines case and dismissed the action against all pawnbrokers that had not dealt with the class representative. The Court was of the view that

under proper circumstances, the plaintiff may represent all those suffering an injury similar to his own inflicted by the defendant responsible for the plaintiff's injury, but in our view he cannot represent those having causes of action against other defendants against whom the plaintiff has no cause of action and from whose hands he suffered no injury. 137

In formulating this principle, the Court did not rely upon standing rules. It was "prepared to assume the presence of standing." 138 In acting pursuant to that assumption, the Court distinguished several decisions of the U.S. Supreme Court ${ }^{139}$ on the basis that

the Supreme Court, in asserting that one who was not a member of a class could not represent that class, was confronted with plaintiffs who had never been injured by the practices about which they complained. In each

is an exception to the usual rule that standing is a threshold question that must be decided prior to class certification issues... Rule 23 certification should be addressed first in those cases where it is the possibility of class certification that gives rise to the jurisdictional issues as to standing.... Stated differently, the Ortiz exception treating class certification as the antecedent consideration does not apply if the standing issue would exist regardless of whether the named plaintiff filed his claim alone or as part of a class. (Clark v. McDonald's Corp., 213 F.R.D. 198 (U.S. Dist. N.J. 2003) at 204 [Clark]).

William D. Henderson, "Reconciling the Juridical Links Doctrine with the Federal Rules of Civil Procedure and Article III" (2000) 67 U. Chi. L. Rev. 1347 at 1374. appellate court decisions dealing with the precise question" canvassed in this article (Moore v. Comfed Savings Bank, 908 F.2d 834 at 838 (11 th Cir. 1990) [Moore]). 
case before us, the plaintiff was injured by a method of dealing more or less common to all defendants. It is because of this distinction that we are prepared for the purposes of this appeal to assume standing. No one contends, of course, that there is no case or controversy between the defendants who seek in these cases to be dismissed and their customers. The issue upon which we turn these cases is whether the plaintiff in each case can represent such customers under Rule 23. ${ }^{140}$

The Court was of the view that the third and fourth prerequisites under r. 23(a), the typicality and adequacy of representation requirements, were directly relevant. In relation to typicality, the Court held that "typicality is lacking when the representative plaintiff's cause of action is against a defendant unrelated to the defendants against whom the cause of action of the members of the class lies." ${ }^{\prime 14}$ Concerning adequacy, the Court was also of the view that "a plaintiff who has no cause of action against the defendant can not 'fairly and adequately protect the interests' of those who do not have such causes of action. This is true even though the plaintiff may have suffered an identical injury at the hands of a party other than the defendant." 142 However, the Court formulated two exceptions to its extremely restrictive construction of the certification requirements:

Obviously this position does not embrace situations in which all injuries are the result of a conspiracy or concerted schemes between the defendants at whose hands the class suffered injury. Nor is it intended to apply in instances in which all defendants are juridically related in a manner that suggests a single resolution of the dispute would be expeditious. ${ }^{143}$

Had the Ninth Circuit anticipated that over the next thirty years those two exceptions, and the second one in particular - commonly referred to as the juridical links exception would be regarded and applied by other federal courts as the law regarding the ability to bring multiple defendant class actions, it would have surely provided more details as to their precise scope and conceptual underpinnings. Instead, La Mar "only briefly discussed what types of relationships might qualify as 'juridical links', and cited a few prior cases where a juridical link was present." 144

The most significant case discussed in La Mar was Washington v. Lee, ${ }^{145}$ in which the Court allowed a plaintiff class action against the Commissioner of the Alabama Board of Corrections who was joined to a defendant class consisting of all county sheriffs and municipal wardens in charge of the state's county and city jails. In that case, the legality of racial segregation in the state penal system and the county and municipal jails was challenged. The Ninth Circuit acknowledged that the Washington class action was certified even though the named plaintiffs did not have a cause of action against each defendant, but the Court went on to explain that

it is also true that all the defendants were officials of a single state and its subordinate units of government.

Their legal relationship distinguishes them from the defendants ... [in the two La Mar class proceedings]. 
Moreover, it was just these juridicial links that were used in Broughton v. Brewer 298 F.Supp. 260 (N.D. Ala. W.D. 1969), to fix the identity of those defendants properly included in the plaintiff's class action to declare Alabama's vagrancy laws unconstitutional brought on behalf of "all persons whose poverty or lack of apparent means of livelihood renders them susceptible to arrest under" such laws. ${ }^{146}$

The Court further regarded the decision in Samuel $v$. University of Pittsburgh ${ }^{147}$ as one based on the existence of juridical links between the defendants in question, namely, state universities that applied a rule which class representatives were challenging on constitutional grounds. In Samuel, the proceedings were certified even though the class representatives attended only the University of Pittsburgh. The Ninth Circuit explained that, "a common rule applied by instrumentalities of a single state [as in Samuel] presents a situation quite unlike that here before us." 148 At the same time, the La Mar judgment contains an unambiguous rejection of Haas, ${ }^{149}$ in which the Court "appeared to believe that a common commercial practice was enough to serve as the legal link present in Washington, Broughton v. Brewer, ${ }^{150}$ and Samuel. With this we do not agree."151 The Court also referred to Weiner ${ }^{152}$ with approval. $^{153}$

La Mar adopted the correct approach by regarding standing principles as irrelevant to multiple defendant class actions initiated by those who do not have personal causes of action against every defendant. ${ }^{154}$ This approach is also in accordance with the recent directive of the U.S. Supreme Court that Rule 23 certification issues are to be considered before standing issues. ${ }^{155}$ But, unfortunately, there are a number of significant problems with La Mar.

La Mar, supra note 4 at 469-70. For similar cases decided prior to La Mar, see Hadnott v. Amos, 295 F.Supp. 1003 (M.D. Ala. 1968); Union Pacific RR v. Woodahl, 308 F.Supp. 1002 (D. Mont. 1970); Rakes v. Coleman, 318 F.Supp. 181 (E.D. Va. 1970); Pennsylvania Association for Retarded Children v. Pennsylvania, 343 F.Supp. 279 (E.D. Pa. 1972); and Lewis v. Baxley, 368 F.Supp. 768 (M.D. Ala. 1973).

56 F.R.D. 435 (W.D. Pa. 1972) [Samuel].

La Mar, supra note 4 at 470.

Haas, supra note 8. In Haas, a Rule 23 proceeding was brought against three banks seeking to recover statutory damages for alleged violations of various Acts. The representative plaintiff had no individual cause of action against one of the three banks but the Court nevertheless granted Haas class representative status as to all three banks.

298 F. Supp. 280 (N.D. Ala. W.D. 1969).

La Mar, supra note 4 at 470 .

Weiner, supra note 132.

Weiner was described in La Mar, supra note 4 at 469 , as "the most nearly apposite case of which we are aware."

See text accompanying notes 88-99 above. See also Cedar, supra note 86 at 330; Kane, supra note 13 at 99; Kohn v. Mucia, 776 F.Supp. 348 at 354-55 (N.D. Ill. 1991); and Greenstein, supra note 128 at 925 , who suggested that

[i]n a class action suit, the function of the named plaintiff, with respect to the claims of the class, is to represent the interests of putative class members, not to supply the injury needed to satisfy the case-or controversy requirement of article III. This latter function is served by the class allegations themselves from the moment they are formally presented to the court in the pleadings.

Because article III concerns are met by the class claims, the question of the plaintiff's standing to litigate those claims has no constitutional significance.

See text accompanying note 131 above. See also Madden, supra note 135 at 610 . It has also been noted that the class standing theory enunciated in La Mar "finds support in other areas of class action litigation, such as the mootness context, in which a named plaintiff who initially had standing may continue to represent the class, even after his personal claim became moot"(R.A. Max, "Defendant Class Suits as a Means of Legal and Social Reform" (1983) 13 Cumberland L. Rev. 453 at 461). 
Specifically, the Court's approval of Weiner is difficult to comprehend, given that it directly conflicts with the conclusion in La Mar that there were no standing problems. ${ }^{156} \mathrm{In}$ fact, it will be recalled that in Weiner it was held that without individual standing to sue each defendant by the class representatives, there was no compliance with Article III. ${ }^{157}$ It is not totally surprising that some courts have regarded the $L a$ Mar exceptions as exceptions to the standing rules. ${ }^{158}$

In general, the Court's approach to the construction and application of class action regimes in La Mar, as shown by the following comments, was excessively restrictive and inconsistent with the philosophy underlying class actions: "Restrictions on the flexible language of Rule 23 [are] a necessary contribution to the effort to avoid the intractable problems of massive class actions and to maintain a wholesome degree of difference between the judicial and administrative functions." 159 Such a judicial approach also displays a failure to appreciate the significant managerial powers that class action regimes confer upon courts. ${ }^{160}$

With respect to La Mar's juridical links exception, the Supreme Court of Montana was entitled to lament that "what constitutes a juridical relationship or link is difficult to define and articulate." 161 The uncertainty surrounding the content of this doctrine is highlighted by the Court's treatment in La Mar of common commercial practices. It is not immediately apparent why the desirable scenario of "all defendants [being] juridically related in a manner that suggests a single resolution of the dispute would be expeditious" 162 can never be attained in the private sector. As the discussion below will show, a number of courts have, in fact, employed the juridical links doctrine to certify multiple defendant class actions where none of the defendants were government officials or units. ${ }^{163}$

See "Class Standing," supra note 13 at 1653: "[t]he courts typically decide questions of adequate representation by invoking rules of justiciability, disallowing as presumptively inadequate any representative who himself lacks standing to sue [citation omitted]. The personal stake requirement hence is made to supply a single answer to two properly distinct inquiries ... [ $\mathrm{La} \mathrm{Mar}]$... exemplifies the conceptual problems of this approach." See also Clark, supra note 134 at 222: "much of the Ninth Circuit's language [in $\mathrm{La} \mathrm{Mar}$ ] is couched in terms evocative of the injury-in-fact requirement of Article III standing."

See text accompanying notes 132-33 above.

See Thillens, supra note 6 at 676: "absent such juridical link, a defendant class fails the Article III test requiring a case or controversy to support the assertion of jurisdiction." See also Thompson v. Board of Education, 709 F.2d 1200 at 1204-205 (6th Cir. 1983) [Thompson Appeal]; Weiss v. Winner's Circle of Chicago, 1995 US Dist LEXIS 18713 at 4 (N.D. Ill.); Angel Music Inc v. ABC Sports, 112 F.R.D. 70 at 74-76 (S.D.N.Y. 1986) [Angel]; Leonard v. Lynch, 64 F.R.D. 432 at 434 (S.D.N.Y. 1974); Brown v. Cameron-Brown Company, 92 F.R.D. 32 at 39, n. 6 (E.D. Va. 1981); Vulcan Society v. Fire Department, 82 F.R.D. 379 at 398-99 (S.D.N.Y. 1979); Akerman, supra note 99 at 375-78; and Alves v. Harvard Pilgrim Health Care, 204 F.Supp. 2d 198 at 205 (D. Mas. 2002) [Alves].

La Mar, supra note 4 at 468. La Mar is a leading example of the judicial hostility towards Rule 23 proceedings that existed in the United States in the early 1970s. See In re AH Robins Co., 880 F.2d 709 at 729-30 (4th Cir. 1989); and A.R. Miller, "Of Frankenstein Monsters and Shining Knights: Myth, Reality, and the "Class Action Problem"' (1979) 92 Harvard L. Rev. 664 at 679. See text accompanying notes 104-106 above. Murer v. Montana State Compensation Mutual Insurance Fund, 257 Mont. 434 at 439 (Sup. Ct. Mont. 1993).

16.3 See text accompanying notes $176-91$ below. 
A more fundamental problem with the juridical links doctrine is that it does not appear to address directly the issues with which the typicality requirement is concerned. The Court of Appeals for the Fifth Circuit explained that the typicality requirement "focuses on the similarity between the named plaintiffs' legal and remedial theories and the legal and remedial theories of those whom they purport to represent." 164 As was aptly pointed out by the Court of Appeals for the Seventh Circuit,

this court has never addressed the juridical link doctrine squarely.... We are sceptical that the use of this terminology is conducive to sound analysis of the kind of problem presented here: the real issues are whether the plaintiff class was injured by the defendants, and if so, whether the claims of the proposed named plaintiffs are representative. ${ }^{165}$

Fortunately, as is explained below, ${ }^{166}$ a majority of courts have interpreted the juridical links exception in a fairly generous manner, thereby enabling it to have a far greater operation than what was intended by the Court in La Mar. ${ }^{167}$ Finally, as noted in Part IV(C) above, the proposition that a plaintiff who has no cause of action against a defendant cannot satisfactorily protect the interests of those who have such causes of action lacks merit. ${ }^{168}$

Flannigan v. Ahearn (In re Asbestos Litigation), 90 F.3d 963 at 976 (5th Cir. 1996), citing Jenkins v. Raymark Indus Inc., 782 F.2d 468 at 472 (5th Cir. 1986). In General Telephone Co. of the Southwest v. Falcon, 457 U.S. 147 at 157, n. 13 (1982), the Supreme Court has explained that the commonality and typicality requirements of Rule 23(a) tend to merge. Both serve as guideposts for determining whether under the particular circumstances maintenance of a class action is economical and whether the named plaintiff's claim and the class claims are so interrelated that the interests of the class members will be fairly and adequately protected in their absence. Those requirements therefore also tend to merge with the adequacy - of - representation requirement, although the latter requirement also raises concerns about the competency of class counsel and conflicts of interest.

Payton, supra note 97 at 679. See also David H. Taylor, "Defendant Class Actions under Rule 23(b)(2): Resolving the Language Dilemma" (1991) 40 Kan. L. Rev. 77 at 105, n. 117: "the La Mar juridical links exception does provide a test that insures that typicality is always met, but it artificially narrows typicality, which can also exist in some situations where there is not a juridical link. The better approach is an independent analysis of typicality in each case." In relation to defendant classes, it has been noted that, "when applying the La Mar rules to defendant class certification, the question is whether the representative defendant is subject to liability to every plaintiff. The focus must be on the defendant representative because the questions of typicality and adequacy of representation respond to the typical nature of this defendant's defenses and the adequacy of this defendant's representation to the defendant class" (In re Itel Securities Litigation, 89 F.R.D. 104 at 119-20 (N.D. Cal. 1981) [Itel]). But see Clark, supra note 134 at $224, \mathrm{n}$. 22 :

it may seem strange that certification of a defendant class could be denied based on the failure of the named plaintiff to satisfy the 'typicality' or 'adequacy-of-representation' requirements relative to the maintenance of a plaintiff class. But that is just a function of the rule set forth in ... La Mar limiting the propriety of a plaintiff class action by reference to the particular defendants against whom it is sought to be maintained. Moreover, in a bilateral class action, the definitions of the plaintiff and defendant classes will reflect opposite sides of the same coin. See text accompanying notes 177-188.

167 Henderson, supra note 135 at 1358 , is of the view that one of the reasons for "[t]he expansion of the juridical link exception ... [may be] the lack of any clear definition for 'juridical link."' Another significant reason for expansion is judicial dissatisfaction with the fact that "the rules set forth in $L a$ Mar substantially restrict the availability of class action treatment in many cases"; Itel, supra note 165 at 119.

168 See text accompanying notes 108-18 above. See also "Class Standing," supra note 13 at 1654: "a personal stake is neither necessary nor even sufficient to guarantee adequate representation. The La Mar court as much as admits the absence of any necessary relationship between the two." 


\section{The CONSPIRACY/CONCERTED ACTION EXCEPTION}

To justify the conspiracy or concerted action exception, the Court in La Mar referred to Contract Buyers League v. $F \& F$ Investment, ${ }^{169}$ a civil rights case relating to discrimination against negroes in Chicago real estate sales. In that case, the Court noted that the defendants' action was concerted and "resulted from a concert and pattern of discriminatory activity including other similar contracts." ${ }^{.70}$ As Henderson observed, this exception "is a relatively narrow category that has been applied in a handful of contexts in which a conspiracy or a concerted scheme among defendants would not necessarily result in joint or vicarious liability."171

An example of the operation of this exception is provided by Thillens. ${ }^{172}$ The plaintiff brought an action against the Community Currency Exchange Association of Illinois (Association), former and current members of the Association (individual defendants), the community currency exchanges owned by those members, and three former Illinois officials (public defendants). Thillens alleged that over 23 years the Association and the individual defendants conspired with the public defendants to restrain Thillens' trade as an ambulatory currency exchange in violation of federal and state antitrust laws. The Court observed that Thillens

alleges that it has been injured by each member of the proposed defendant class. Instead of being an amorphous entity, the proposed defendant class of currency exchanges and their individual owners is highly cohesive and self-organised. It is juridically linked at least by allegations that each defendant class member voluntary joined a conspiracy to harm Thillens. ${ }^{173}$

\section{E. ThE JURIDICAL LINKS Doctrine}

The cases referred to in La Mar to illustrate and justify the juridical links doctrine involved Rule 23 proceedings brought against state officials applying common rules. Therefore, it was not surprising that a 1975 judicial description of the exception suggested that

such "juridical links" would most often be found in instances where all members of the defendant class are officials of a single state and are charged with enforcing or uniformily acting in accordance with a state statute, or common rule or practice of state-wide application, which is alleged to be unconstitutional. ${ }^{174}$

300 F.Supp. 210 (N.D. Ill. 1969)

Ibid. at 214.

Henderson, supra note 135 at 1359-60. See also Shafner, supra note 9 at 501-502.

Thillens, supra note 6.

Ibid. at 676. See also the cases discussed in Shafner, supra note 9 at 501-502; and Henderson, supra note 135 at $1359-61$.

$174 \quad$ Mudd v. Busse, 68 F.R.D. 522 at 527-28 (N.D. Ind. 1975). See also Thompson Appeal, supra note 158 at 1205; Moore, supra note 136 at 838; and Akerman, supra note 99 at 376: "courts have also shown a willingness to find that named plaintiffs have standing to sue a class encompassing some defendants against whom they individually might not have a cause of action on the ground that the plaintiff class as a whole has been victim of a unified governmental policy carried out by the individual defendants." It has been held, however, that "defendants are not juridically related where their discretionary conduct is challenged" (Streich, supra note 91). See also Coleman v. McLaren, 98 F.R.D. 638 at 649 (N.D. Ill. 
An example of this scenario is found in Marcera $v$. Chinlund. ${ }^{175}$ In that case, the Court of Appeals for the Second Circuit upheld the certification of a statewide plaintiff class of inmates and a defendant class of 42 sheriffs who denied contact visitation for pre-trial detainees. The representative plaintiff sought to establish that such denial was unconstitutional. Inmates of one jail had no dealings with, and therefore no personal cause of action against, the sheriffs of counties other than that in which they were incarcerated. However, the Court found that challenging the validity of such a state-wide practice was indistinguishable from challenging the validity of a statute:

We recognize that this case is not precisely congruent to the usual suit against a class of local public officials. Plaintiffs here are not attacking the facial validity of a locally administered statute of statewide effect ... but rather a series of similar administrative practices. Nevertheless, the distinction is immaterial under the facts of this case. The challenged behaviour of the 42 sheriffs - denial of contact visitation - is identical; it could not be more so were they acting pursuant to statute rather than their own administrative policies. ${ }^{176}$

It did not take long for courts to apply the juridical links doctrine to non-governmental officials and entities. For instance, in the 1977 case of United States $v$. Trucking Employers Inc. ${ }^{177}$ the doctrine was relied upon to certify a defendant class consisting of all trucking companies that were parties to, or bound by, the National Master Freight Agreement and area supplements. The companies in question were accused by the plaintiffs of engaging in employment discrimination. In concluding that the defendants were juridically related pursuant to the La Mar exception, the Court observed that

here, each member of the defendant class provides an identical service, requires employees who possess identical skills, and utilises identical job classifications. Perhaps most telling, each is a party to the National Master Freight Agreement or its area supplements. These agreements bind the employment practices of the entire class in certain crucial respects... Thus, these agreements serve a function analogous to that served by the statutes at issue in Washington $v$. Lee ${ }^{178}$ and Gibbs v. Titelman.... ${ }^{179}$ First, the agreements delimit the defendant class. Indeed, this bond between the class members suggests to the court that in a practical sense

1983); Doss, supra note 6 at 116; and Mudd, 68 F.R.D. 522 (N.D. Ind. 1975).

595 F.2d 1231 (2nd Cir. 1979).

Ibid. at 1238, n. 10. See also Payton, supra note 97; Driver v. Helms, 74 F.R.D. 382; Doss, supra note 6 at 120; DeAllaume v. Perales, 110 F.R.D. 299 at 303-304 (S.D.N.Y. 1986); Luyando v. Bowen, 124

F.R.D. 52 at 58-59 (S.D.N.Y. 1989); Harris v. Graddick. 593 F.Supp. 128 at 136-37 (M.D. Ala. 1984); Kendall v. True, 391 F.Supp. 413 at 417 (W.D. Ky. 1975); Ragsdale v. Turnock, 625 F.Supp. 1212 at 1223 (N.D. Ill. 1985); Hopson v. Schilling, 418 F.Supp. 1223 (N.D. Ind. 1976); and Monaco v. Stone, 187 F.R.D. 50 at 53-54 (E.D.N.Y. 1999). It is interesting to note that in Turpeau v. Fidelity Financial Services Inc., 936 F.Supp. 975 at $978-79$ (N.D. Ga. 1996), it was held that no juridical link existed among defendant lenders and life insurance companies although each was alleged to have violated the same statute in the same manner. This conclusion was based on the fact that the defendants were not state officials charged with enforcing state statute or common rule or practice.

75 F.R.D. 682 (D.D.C. 1977) [Trucking]. See also Alaniz v. California Processors Inc., 73 F.R.D. 269 at 276 (N.D. Cal. 1976); and Follette v. Vitanza, 658 F.Supp. 492 at 508 (N.D.N.Y. 1987).

General description of this case in text accompanying supra note 145.

369 F.Supp. 38 (E.D. Pa. 1973). The plaintiffs challenged the constitutional validity of a statutory scheme concerning repossession of motor vehicles and sought as well an order to restrain General Motors Acceptance Corporation and others similarly situated from continuing their practices of effecting extrajudicial non-consensual repossession of motor vehicles. The Court certified both a plaintiff class and a defendant class in light of the fact that the relief sought was "really against the statute, not the defendants" (ibid. at 53). 
they themselves have elected to become a "class". Second, the legality of certain provisions of these agreements is at issue in this case. ${ }^{180}$

The gradual judicial expansion of the juridical links doctrine may be gauged by comparing the 1975 description of the exception set out above with the definition provided in the 1984 case of Akerman, which asserted that ${ }^{181}$

[a] juridical link sufficient to confer standing generally must stem from an independent legal relationship.

Partnership, joint enterprise, control, conspiracy, and aiding and abetting all may serve as such a link, since they denote some from of activity or association on the part of the defendants that warrants imposition of joint liability against the group even though the plaintiff may have dealt primarily with a single member. ${ }^{182}$

Accordingly, the juridical links exception has been applied to justify certification where the defendants used identical registration statements and prospectuses, ${ }^{183}$ where the defendants shared common ownership, ${ }^{184}$ and where a group of defendant underwriters entered into an agreement among themselves concerning the relevant underwriting. ${ }^{185} \mathrm{~A}$ broad interpretation of this doctrine has also been adopted by appellate courts. In Moore,${ }^{186}$ for instance, the class representatives borrowed money from Land Bank Equity Corporation. The bank, in turn, sold the promissory notes to savings and loan institutions around the country. The lenders were joined as defendants in a Rule 23 proceeding, but seven of the lenders did not hold any promissory notes of the representative plaintiffs. Relying on the juridical links exception, the Court of Appeals for the Eleventh Circuit held that the seven defendants in question were properly joined. In so holding, the Court endorsed the following comments that had been made by the trial judge:

Trucking, supra note 177at 689-90. Marcera, supra note 174, and Trucking further illustrate the fact that $L a$ Mar applies "not only when multiple defendants are sued individually, but also when multiple defendants are sued as members of a class" (Clark, supra note 134 at 223-24). Supra note 99.

Ibid. at 375. See also Thillens, supra note 6 at 676: "a 'juridical link' is some legal relationship which relates all defendants in a way such that single resolution of the dispute is preferred to a multiplicity of similar actions" (Madden, supra note 135 at 609); Moore, supra note 136 at 838; and Angel, supra note 158 at 77: "[courts] have carved out an exception for defendant classes whose conduct is standardized by a common link to an agreement, contract or enforced system which acts to standardize the factual underpinnings of the claims and to insure the assertion of defenses common to the class."

See Itel, supra note 165 at 121-23. But see Akerman, supra note 99 at 376: "a defendant class may not be certified simply on the ground that underwriters distributed identical printed matter to securities purchasers."

See e.g. Alves, supra note 158 at 205; Texas Commerce Bank Nat. Assoc. v. Wood, 994 S.W.2d 796 at 807 (Tex. App. - Corpus Christi 1999); and Barker v. FSC Sec. Corp., 133 F.R.D. 548 at 553 (W.D. Ark. 1990). Litigation, 621 F.Supp. 415 at 432 (N.D. Cal. 1985); and In re Computer Memories Securities Litigation, 111 F.R.D. 675 at 681 (N.D. Cal. 1986). 
Other named plaintiffs could be supplied to match with each named defendant but it would be unwieldy to do so. Each plaintiff and the defendants have connection to each other through Land Bank equity. The case is simpler and more economical with the class of plaintiffs and the named defendants. ${ }^{187}$

Therefore, as Henderson observed, "[o]ver time, the juridical link exception's focus on a uniformly enforced rule or agreement has gradually been supplanted by a more general emphasis on judicial efficiency." 188

Comments made by the District Court for the Northern District of Illinois in Coleman $v$. McLaren ${ }^{189}$ highlight the extent of the confusion and uncertainty generated by judicial application and interpretation of the juridical links doctrine. The Court pointed out that there were two divergent ways in which courts applied the typicality and adequacy of representation requirements to multiple defendant class actions. The more stringent of these methods was exemplified in La Mar; other courts employed "a more flexible and functional test in determining compliance with Rule 23(a)(3) and (4).... That approach permits facial challenges to similar, but independently inspired, express policies or practices of nonjuridically related defendants." ${ }^{\prime 90}$ It is fascinating to note that some of the authorities for this flexible approach mentioned in Coleman ${ }^{191}$ and Thompson $^{192}$ were cases in which the courts expressly applied the juridical links exception formulated in La Mar. ${ }^{193}$ The analysis developed in Coleman aptly illustrates that the ambiguity of the juridical links doctrine has enabled a number of courts to assert that they were applying the doctrine when, in fact, they were applying quite different principles and techniques. ${ }^{194}$

Moore, supra note 136.

188 Henderson, supra note 135 at 1358. Henderson further explained,

[f]or example, in Weiss v. Winner's Circle of Chicago, Inc. a Rule 23(b)(3) plaintiff class joined three defendants ... because they had provided financing to consumers through another defendant, who had utilized fraudulent sales practices. [citation omitted] Although the named plaintiff had no cause of action with regard to two of the defendants, the court applied the juridical links exception because 'it would be expeditious to allow the lender defendants to be joined and obtain a single resolution' [citation omitted].

98 F.R.D. 638 (N.D. Ill. 1983).

Ibid. at 648-49.

See text accompanying notes $176-79$ above.

Supra note 6 at 418 . In Thompson, this case, the Court certified the following plaintiff and defendant classes in relation to claims under Title VII of the Civil Rights Act of 1964:

Defendant class: All school boards in the State of Michigan which, since March 24, 1972, have treated or now treat pregnancy related disabilities differently than other temporary disabilities, limited to the school boards in districts wherein the [Michigan Education Association] has female members who have been or will be subject to such policies or practices. Plaintiff class: All female teachers of such school boards who have been since March 24, 1972 or will be in the future, denied the benefits of a sick leave policy which treats pregnancy related disabilities the same as other temporary disabilities.

See Trucking, supra note 177 at 690; and Thompson, supra note 6 at 409, n. 19:

the 'judicially related' exception ... is equally appropriate in this case. There is substantial merit to the proposition that when multiple school districts, in a statewide system of education, establish programs for paid disability leave which exclude pregnancy, by individual negotiation with employee bargaining representatives, by policy or by regular practice, they create a juridically related problem appropriately justiciable in a class action [emphasis in original].

But see Angel, supra note 158 at 75 , where the Court warned that "a broad construction of the juridicial link exception to La Mar obscures the confines of that doctrine." 


\section{F. GenERAL ObSERVATIONS}

The analysis of United States jurisprudence regarding the relevance and impact of standing principles upon multiple defendant class actions has revealed the existence of a grossly unsatisfactory scenario. It further illustrates the need for an unambiguous statement by the U.S. Supreme Court to the effect that the only relevant question for standing purposes is "whether the class as a whole has standing to sue the named defendants, rather than upon the narrow question of whether each named plaintiff meets the traditional standing requirements against each named defendant."'195

What is also required is a judicial approach to what compliance with the typicality requirement entails in multiple defendant class actions which adheres to the following line of reasoning: "where the court can fairly conclude that by pursuing their own interests vigorously the named representative will necessarily raise all claims or defenses common to the class, representativeness will be satisfied."196

\section{CONCLuSION}

This article has explored the judicial pronouncements of the Federal Court of Australia, courts in the Canadian provinces of Ontario and British Columbia, and U.S. Federal Courts in relation to the crucial issue of what relevance, if any, standing rules should have upon attempts to initiate and prosecute class proceedings against multiple defendants by representative plaintiffs who have personal claims against only some of the defendants. The analysis has revealed that in most cases an extremely restrictive judicial approach is implemented, pursuant to which the standing rules that are applied with respect to class proceedings are, to a large extent, those which are employed in traditional or non-group litigation.

The most extreme illustration of this approach is provided by the decision of the Full Federal Court of Australia in Philip Morris where it was held that multiple defendant class actions are not permitted unless the court is satisfied that all of the named plaintiffs and class members have personal claims against each of the defendants. In Ontario, a more liberal approach is followed. Multiple defendant proceedings may be certified as class proceedings as long as for each defendant there is a representative plaintiff with a personal claim against that defendant. The rules and principles governing this issue in the United States are less clear, as the somewhat elastic and uncertain concept of a juridical link among the defendants has been employed. In contrast, courts in British Columbia have adopted the most enlightened approach, holding that multiple defendant class proceedings should be treated like any other class proceedings once it has been shown that there is a plaintiff who has a 
direct claim against one of the defendants, and, moreover, that there are some members of the group/class who have a personal cause of action against each named defendant.

It will be interesting to see which of these approaches Alberta courts follow in relation to multiple defendant class actions as they are brought forward pursuant to the new, comprehensive class proceedings regime introduced by the Class Proceedings Act ${ }^{197}$ that received royal assent on 16 May 2003.

\section{POSTSCRIPT}

In July 2003 Carr and Finkelstein JJ. of the Full Federal Court of Australia in Bray v. Hoffmann-La Roche Ltd. ${ }^{198}$ indicated that Philip Morris should not be followed "to the extent that it is authority for the proposition that, where there is more than one [defendant], every class member must have a claim against every [defendant] in a [Part IVA] proceeding, on the basis that [Philip Morris] was clearly wrong on that point." 199 The third justice deciding the case, Branson J., indicated that Philip Morris should be followed unless and until the High Court of Australia takes a different view as to the proper interpretation of s. 33C(1) of Part IVA. However, she added, "notwithstanding my view that this Court should follow Philip Morris, I would not reject the possibility that s. $33 \mathrm{C}(1)$ allows an applicant who has a claim against more than one respondent to [commence] a representative proceeding on behalf of more than one group (e.g. on behalf of two subgroups of members where within each subgroup each member has a claim against the same respondent or respondents).,"200

Ibid. at para. 130, Carr J. See also ibid. at 246-448, Finkelstein J. Justice Carr's views were obiter dicta, for he held that Philip Morris had been complied with in the class proceedings before him, as each class member had a claim against each defendant.

Ibid. at para. 200. With all due respect, Branson J.'s views on this issue are extremely unclear. The example she provided of a multiple defendant class action that may be brought under the Part IVA regime is directly in conflict with Philip Morris - a case she supported. In fact, in that example, it cannot be said that each class member had a claim against each defendant as the members of one subgroup do not appear to have claims against the defendants who harmed the members of the other subgroup. 